\title{
The in Vitro Secretion of Growth Regulators by Isolated Callus Tissues
}

\author{
Alan Lung-Ming Lin \\ College of William \& Mary - Arts \& Sciences
}

Follow this and additional works at: https://scholarworks.wm.edu/etd

Part of the Physiology Commons

\section{Recommended Citation}

Lin, Alan Lung-Ming, "The in Vitro Secretion of Growth Regulators by Isolated Callus Tissues" (1972). Dissertations, Theses, and Masters Projects. Paper 1539624758.

https://dx.doi.org/doi:10.21220/s2-cj37-8h92

This Thesis is brought to you for free and open access by the Theses, Dissertations, \& Master Projects at W\&M ScholarWorks. It has been accepted for inclusion in Dissertations, Theses, and Masters Projects by an authorized administrator of W\&M ScholarWorks. For more information, please contact scholarworks@wm.edu. 
TEE IN VITRO SECRETION OF GRONTH REGULATORS BY ISOTATED

CALITS TISSUES

\begin{abstract}
A Thesis
Presented to

The Faculty of the Department of Biolog,

The College of William and Mary in Vireiria
\end{abstract}

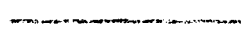

In Partial Fulfilment

of the Requirenents for the legree of

Master of Arts
\end{abstract}

By

Alan Lung-Ming Lin

1972 
ProQuest Number: 10625203

All rights reserved

INFORMATION TO ALL USERS

The quality of this reproduction is dependent upon the quality of the copy submitted.

In the unlikely event that the author did not send a complete manuscript and there are missing pages, these will be noted. Also, if material had to be removed, a note will indicate the deletion.

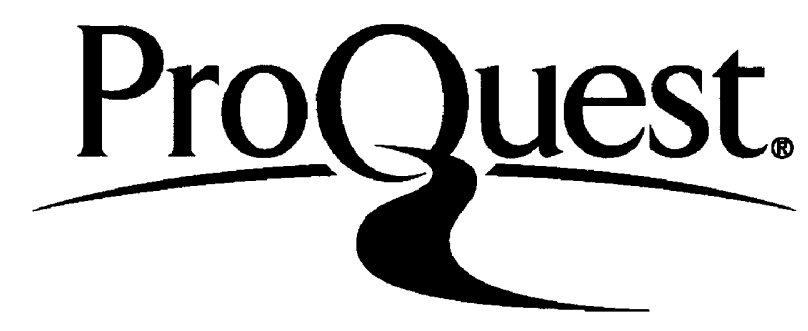

ProQuest 10625203

Published by ProQuest LLC (2017). Copyright of the Dissertation is held by the Author.

All rights reserved.

This work is protected against unauthorized copying under Title 17, United States Code Microform Edition (c) ProQuest LLC.

ProQuest LLC.

789 East Eisenhower Parkway

P.O. Box 1346

Ann Arbor, Ml 48106 - 1346 
APPROVAL SHEET

This thesis is submitted in partial fulfillment of the requirements for the degree of Master of Arts

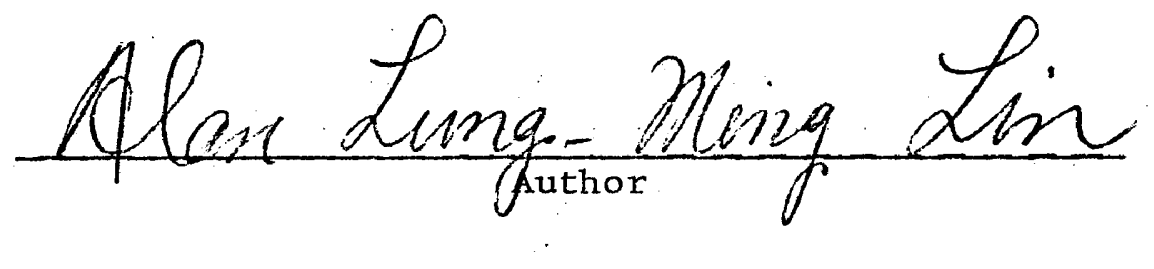

Approved, January 1972
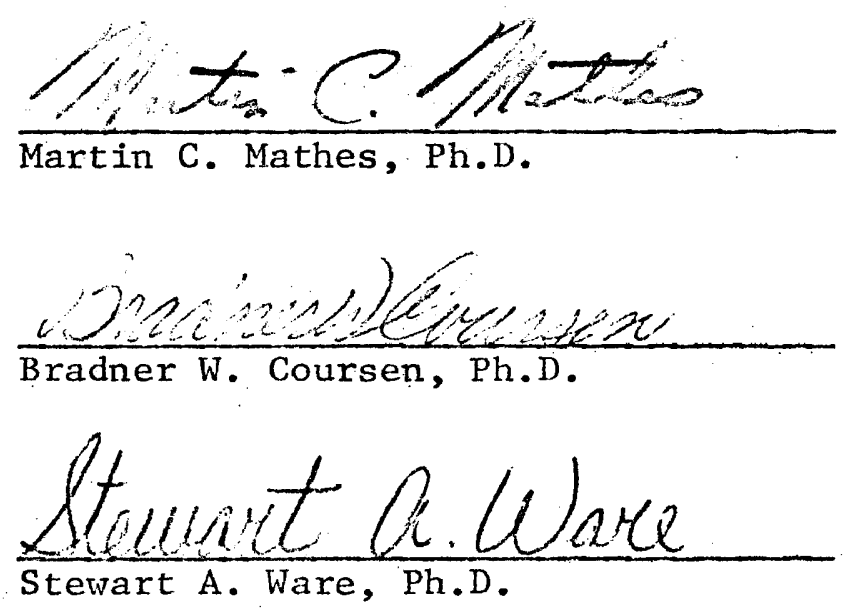

$$
\begin{aligned}
& \text { 52. } \\
& \text { Ref. }
\end{aligned}
$$




\section{ACKNOWIEI)GMNTS}

The wrjter wishes to express his gratitude to Professor Martin $C$. Nathes for his guidance and patierce during the investigation of the problem. The author also extends his appreciation to Professor Stewart A. Ware and Professor Bradner $W$. Coursen for their reading and criticism of the emperimental work. 


\section{TABLE OF CONTENTS}

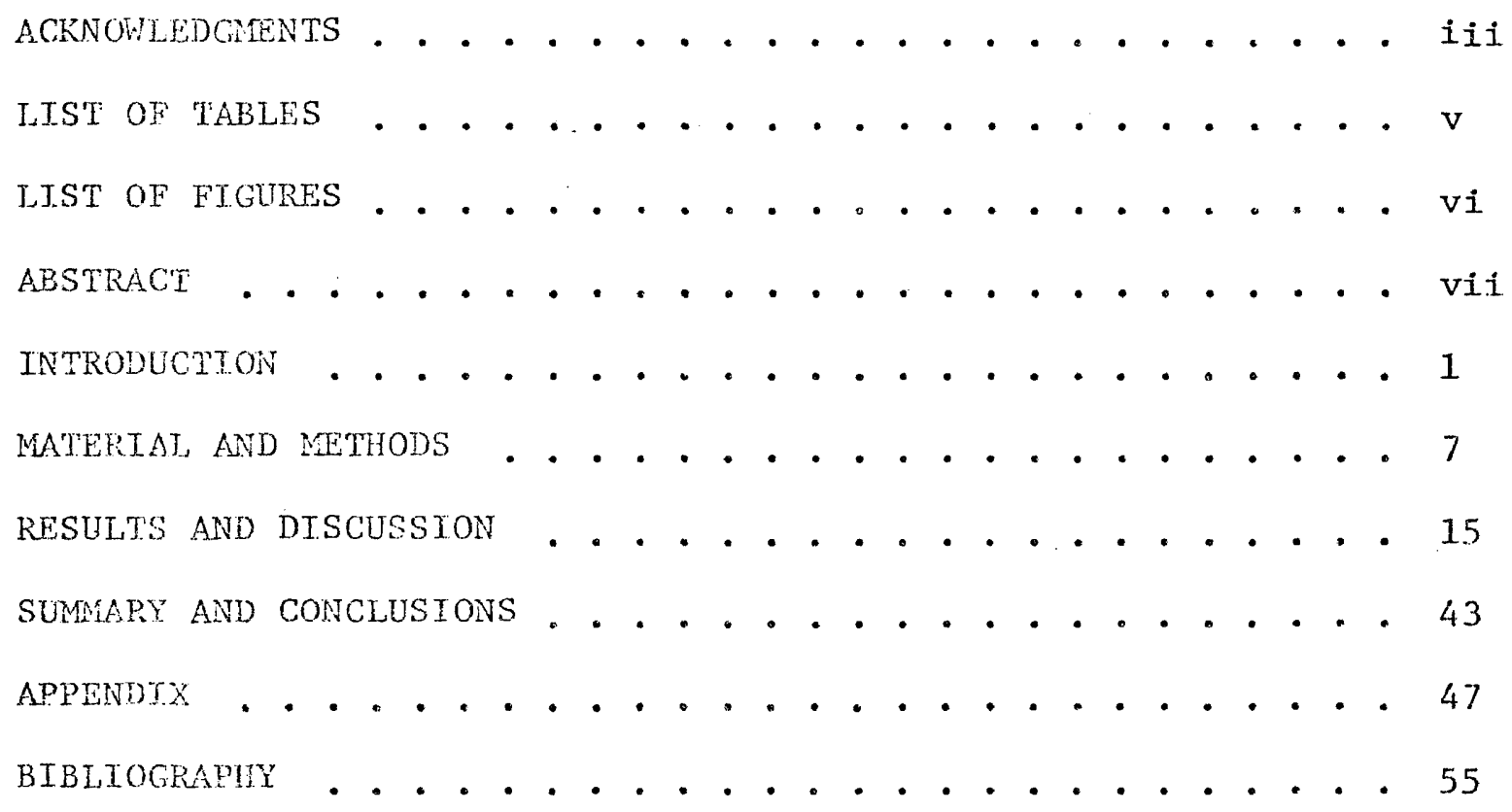


1. The growth of isolated callus on selected media... . . . . . . . . . . 16

2. The inhibition of the growth of Bacillus subtilis by isolated callus tissues . . . . . . . . 21

3. The influence of isolated callus growth on the growth of Lerma minor . . . . . . . . . . . 25

4. The influence of isolated callus growth on the germination and growth of tomato seeds . . . . . . . 31

5. The influence of juice expressed from isolated callus tissues on the growth of Lemna minor . . . . . . . . . . . . . . 38

6. The influence of extracts of isolated callus tissues on the growth of Lemna minor . . . . . . . . . . . . . . . . . . 39

7. Summary of the secretion of growth regulators from isolated callus tissues . . . . . . . 44 


\section{LIST OF FIGURES}

Figure

Page

1. Arrangement of tomato seeds or Lemna plantlets during bioassay for growth regulators . . . . . . . . 10

2. The inhibition of the growth of Bacillus subtilis in the presence of secretions of aspen callus tissue . 20

3. The growth of Lema minor in the presence of secretions from aspen callus tissue... . . . . . . 24

4. The growth of Lemna in the presence of materials secreted by isolated aspen callus tissue . . . . . . 26

5. The growth of Lemna in the presence of materials secreted by isolated serviceberry callus tissue . . . . 27

6. The growth of Lemna in the presence of materials secreted by isolated pokeberry callus tissue . . . . 28

7. The germination of tomato seeds in the presence of secretions from isolated peach callus tissue . . . . 30

8. The germination of tomato seeds in the presence of materials secreted by isolated peach callus tissue . . . . . . . . . . . . . . 32

9. The germination of tomato seeds in the presence of materials secreted by isolated sweet potato callus tissue... . . . . . . . . . . . . 33

10. The germination of tomato seeds in the presence of materials secreted by isolated serviceberry callus tissue. . . . . . . . . . . . . . 34

11. The growth of Lemna in the presence of water extract of isolated ginkgo callus tissue . . . . . . . 40

12. The growth of Lemna in the presence of ethyl. ether extract of isolated peach callus tissue . . . . . 4 42 


\section{ABSTRACT}

Plant materials were surface sterilized and callus tissues were isolated from a wide variety of plants. The rate of production and subsequent growth of callus tissues in different media were studied.

Isolated tissues were bioassayed for growth regulatory activity. The assay organisms in this study included Escherishia coli, Bacillus subtilis, Sarcina 1utea, Chlorel1a sorokiniana, Lemna minor and seeds of Lycopersicon esculentum. The secretions from four (Amelanchier alnifolia, Ipomoea batatus, Phytolacca americana and Populus tremuloides) of the 20 callus tissues inhibited the growth of Bacillus subtilis. An aseptic. method for measuring the growth of Lemna was developed and used to detect inhibitory materials in mediun which had supported the growth of seven (Ginkgo biloba, Amelanchier alnifolia, Populus tremuloides, Ipomoea batatus, Cichorium intybus, Phvtolacca americana and Lactuca sativa) isolated callus tissues. In the seed germination test, seven (Amelanchier alnifolia, Ipomoea purpurea, Acer negundo, Plantago ovata, Ginkgo biloba, Prunus persica and Lactuca sativa) callus tissues had an inhibitory influence while two (Ipomoea batatus and Solanum tuberosum) callus tissues showed a stimulatory effect. Two (Populus tremuloides and Phytolacca americana) callus tissues inhibited the growth of Chlorella.

The study also included expressed juices and extracts of callus tissues which secreted regulatory materials. The expressed juice of $\operatorname{six}$ (Amelanchier alnifolia, Cichorium intybus, Ginkgo biloba, Ipomoea 
batatus, Phytolacca americana and Populus tremuloides) callus tissues contained materials which inhibited the growth of Lemna. Two (Populus tremuloides and Phytolacca americana) expressed juices inhibited the growth of Bacillus subtilis and Chlorella. The water and ethyl ether extract of Ginkgo biloba callus tissue, the water and ethyl ether extract of Ipomoea batatus callus tissue and the ethyl ether extract of Prunus persica callus tissue inhibited the growth of Lemna.

Fifty percent of the plants which produce growth regulatory materials in nature also produced callus tissue which was capable of regulating growth of assay organisms. It is concluded that tissue grown in vitro may produce the same or different growth regulators as the intact plants. 
THE IN VITRO SECRETION OF GROWTH REGULATORS

BY ISOLATED CALLUS TISSUES 


\section{INTRODUCTION}

Many plant/plant interactions are due to competition for nutrients, water or: Iight and relative susceptibility to insects or disease. DeCandole (1832) first raised the question of the existence of natural plant growth inhibitors and the role of these substances in plant ecology and competition. The production of plant materials which can influence the growth of plants is now well documented in the plant kingdom.

A number of plant species have been reported to produce plant growth regulators. Cook (1921) investigated the inhibition of potato and tomato plants by substances produced by black walnut trees while Massey (1925) studied the cause of wilting of potato, tomato and alfalfa plants due to a biack walnut tree (Juglans nigra) growing in the immediate vicinity. Massey (1925) also reported that the root bark of walnut contains a matexial which is toxic to the roots of tonato plants grown in water culture. Schneiderhan (1927) further investigated the death of field-grown apple trees as a result of a black walnut tree growing in the vicinity. These trees produced a toxic material which Davis (1928) identified and named "juglone".

Plant inhibitors produced by the roots of brome grass (Bromus jaemis) were demonstrated by Benedict (1941) after Proebsting and Gitmore (1940) reported difficulty in re-establishing peach trees in soil which had previously supported peach orchards. Patrick (1955) confirmed the peach trees replanting problem and studied the toxic substance released from the decayed peach root residues. Hendershott and Walker 
(1959, 1959) identified a growth inhibitor from extracts of dormant peach flower buds and related seasonal fluctuations in the quantity of growth substances with dormancy. Dennis and Edgerton (1961) studied the relationship between growth and an inhibition which Corgam (1965) suggested may be the result of changes in an hydroxy flavanone (naringenin) concentration in peach flower buds. Erez and Lavee (1968) suggested that another chemical (prunin) may act as a precursor for naringenin and it also had a seasonal quantitative change in peach buds.

Waks (1936) showed that the roots of Robinia pseudoacacia contained a chemical which strongly inhibited other species. Inhibitors have also been reported in the leaves of Artemisia absinthium (absinthin) (Bode 1950, Funk 1943), in guayule seedlings (transcinnamic acid) (Bonner 1950), fn the leaves of Encelia farinosa (Gray and Bonner 1948, 1948) and in the seeds of Psoralea subacaulis (Baskin et a1. 1967).

The antimicrobial activity of plant extracts has been reviewed by . Osbom (1943) and Nike11 (1960). Allelopathic effects of Malus domestjca, Nicotiana tobacum, plantenus occidentalis and Celtis laevigata have been investigated (Bonner 1959, Cutler 1970, A1-Naib and Rice 1971, Lodhi and Rice 1971). Ginkgo biloba, because it is the most ancient tree in the world, has been studied to deternine the basis for its resistance to insects, bacteria, virus and fungi (Major 1967).

Plant inhibitors have been reported from a wide range of plant parts in addition to the diversity of species. Numerous studies (Osvald 1948, Hamilton and Buchholtz 1955, Kommedah1, Kotheimer and Bernardini 1959, Ohman and Kommedah1 1960, Welbank 1963, Patrick, Toussoun and Koch 1964, Carley and Watson 1968) with quackgrass (Agropyron repens) and other species have indicated aqueous extracts of various plant organs 
will inhibit the germination of weed and certain crop seeds. Materials, including growth regulators, leached out from the above ground plant parts have also been investigated. Allelopathy due to phototoxic root exudates has been reported by Woods (1960), Ballantyne (1962) and Rovira (1969). Muller and Muller (1964) and Muller (1965) studied the volatile material emanating from leaves of Salvia species. Plant growth inhibitors which vary according to the season are also present in xylem sap of wood species (Davison 1964, Voigt and Mergen 1962, Robinson and Wareing 1964).

Very few workers have reported the presence of natural growth stimulators other than auxin. Root promoting substances in Hedera helix and Salix alba have been reported by Giroward and Hess (1964) and Kawase (1970). Allelopathy has been extensively studied recently, and according to Tukey (1969) a full and intensive evaluation of this phenomenon is long overdue.

The use of tissue culture in studies involving the production of metaboljtes, such as growth regulators, has been discussed by numerous investigators (Steward and Caplin 1952, Klein 1960, Mathes 1963, 1967, Mathes, Morsel1i and Marvin 1971, Campbe11, Chan and Barker 1965, Khanna and Staba 1968, Barker 1970). Sterile stem sections contain meristematic cells which start to divide to form callus tissue on an appropriate medium. The use of the tissue culture system permits growth of the tissues for an indefinite period, under rigidly controlled conditions with minimal physical, chemical and environmental fluctuations. Tissue grown in vitro may produce the same or new metabolites as present in the intact plant parts which were used to produce the initial callus. According to Rajasekhar et a1. (1971), tissues cultured under different conditions 
may produce different kinds of metabolites, i.e. growth inhibitors, which may influence the rate of tissue growth. The role of environmental factors on the metabolism of callus tissue can be easily and clearly studied under standardized conditions with one variable.

Tissue culture procedures can also eliminate the necessity of chemical extraction because of the secretion of materials into the medium and can be utilized in a program to screen various isolated tissues for the presence of antimicrobial materials (Mathes 1967).

In recent years, studies using callus tissue from diverse sources of plant material and various plant parts have reported a number of materials, including enzymes, which were secreted into the tissue culture media. Nickell and Brakke (1954) demonstrated the migration of alnha anylase from explanted Rumex virus tumors while Mathes (1964, 1967) and Mathes et a1. (1971) showed that isolated aspen and sugar maple callus tissue secrete materials which can bring about the extracellular digestion of starch in the culture medium. Weinstein et al. (1962) showed that callus tissues may be cytologically, physiologica11y and biochemically different from intact part of the plant which they are derived. This work suggests the use of tissue culture for the production of new materials. Campbe11 et a1. (1965) reported that antimicrobial substances were not present in intact parent plant.

Mathes (1963) discussed the tissue culture of aspen and the production of compounds which inhibited the growth of many fungi and bacteria. This study was followed Mathes (1967) by the detection of antimicrobial activity in the culture medium after the growth of various isolated tissues. Khanna and Staba (1968) also studied the antimicrobial activity of isolated plant tissues in static and suspen- 
sion cultures and found that $80 \%$ of these cultured tissues demonstrated antimicrobial activity. Maheswari et a1. (1967) showed snapdragon (Anthirrhinum majus) tissue cultures produced an extracellular material which inhibited the germination of the rust urediospores. Barker (1970) has also investigated the influence of metabolites produced by explants on the growth of the other explants.

The detection of regulatory materials produced by actively growing isolated tissues depends on the production and secretion of growth regulators at levels which will inhibit the growth of test organisms. Since growth regulators are present in plants in extremely small quantities, bioassays are frequently the only available methods of analysis sersitive enough to detect these biologically active compounds (Tukey 1969). Various methods for the detection of growth regulators were modified for use in the present study.

The primary objective of this study was to investigate the secretion of growth regulators by various isolated tissues and determine their in vitro activities against different assay organisms. Suitable. assay methods for the detection of growth regulators secreted by the isolated tissues were developed and actively growing tissue cultures were obtained from selected species. Comparisons of the growth regulator actjvity between the intact plant and the isolated callus tissue from plants which have allelopathic or antimicrobial activities were made. Plants which have been reported to produce growth regulators were used as a source of callus tissues in the assay for active materials. Plants which have not been reported to produce growth regulators were also included to discover additional active materials. The majority of the plants utilized in this investigation have been 
previously reported to have allelopathic or antimicrobial activity. 
MATERIALS AND METHODS

TISSUE ISOLATION AND SOURCES

Most of the isolated callus tissues used in this investigation were isolated from the cambial area of internodes of actively growing material in 1970. Stem sections about $7 \mathrm{~cm}$ long were cut and surface sterilized with a commercial sodium hypochlorite solution ( $5.25 \%$ ) containing a few drops of wetting agent (Tween 20) to decrease the surface tension. The sections were immersed for 10-15 minutes and rinsed 3 times in sterile distilled water. An alternative method involved dipping the tissue into $70 \%$ alcohol for two minutes before immersion in commercial sodium hypochlorite for 10-15 minutes and rinsing three times in sterile distilled water. In the third method, tissue sections were immersed in a $0.1 \% \mathrm{HgCI}_{2}$ solution containing several drops of Tween 20 for 15 minutes and then immersed in $0.1 \mathrm{M} \mathrm{NH} 2 \mathrm{OH} \mathrm{HCl}$ solution for 10 minutes. This treatment was followed by an additional immersion in $0.1 \% \mathrm{HgCl}_{2}$ solution for 10 minutes and $0.1 \mathrm{M} \mathrm{NH}_{2} \mathrm{OH} \mathrm{HCl}$ solution for a final 10 minutes. After these steps the plant parts were rinsed three times in sterile distilled water. The results of sterilization by the second and third methods did not show an increase in sterilization efficiency over the first method. Increasing the time of each interval in all three methods to 20 minutes did not decrease the amount of contamination so the first method was used to sterilize most of the tissues in this study. The sterilized stem sections were cut into pieces approximately $3 \mathrm{~mm}$ in length after the end sections were discarded. The sections 
were incubated in the dark at $27 \pm 1^{\circ} \mathrm{C}$ on solid medium. Three media were used to determine their effects on the rate of callus tissue production and the rate of isolated tissue growth. Callus production was observed and tissues were 1solated and subcultured in the medium which resulted in the most rapid proliferation for that tissue. The three kinds of media used in this study were designated as IK, 2,4-D and 23 (Appendix, Table 1). Linsmaier and Skoog's (1965) defined medium was supplemented with $1.0 \mathrm{ppm} 2,4$-dichlorophenoxyacetic acid was substituted for IAA and kinetin (2,4-D medium). The 23 medium (Appendix, Table 2) contained White's (1942) major salts, Nitsch's (1951) minor elements, $2 \%$ sucrose, $0.8 \%$ agar, $10 \%$ coconut milk and $0.5 \%$ naphthaleneacetic acid. The coconut milk was heated to $60^{\circ} \mathrm{C}$, cooled, and filtered (Whatman No. 1 filter paper) before incorporation into the medium. All materials were added to the medium, the pH was adjusted to 5.6 and the medium was autoclaved for 20 minutes at $121^{\circ} \mathrm{C}$ and $15 \mathrm{psi}$. Callus produced by the sterile stem sections was excised after a growth period of 6-8 weeks. Isolated callus tissue was transfered frequently (3-4 weeks) to assure active growing tissues. Relatively large ( $80-100 \mathrm{mg})$ pieces of tissue were used as inoculum in the experiments because the growth rate of the smal1 tissue pieces (approximately $40 \mathrm{mg}$ ) usually involves a longer lag period. This effect has been observed by Yeoman, Naik, and Robertson (1968) and suggested to be the result of autolysis products which can stimulate the growth of callus tissue.

Callus tissue from sweet potato, aspen (isolated in 1961), sugar maple (isolated in 1965), carrot, tobacco, white potato and plantain which were used in this study were obtained from Martin C. Mathes, 
College of William and Mary. The remainder of the tissues used in this investigation were isolated by the author.

\section{BIOASSAY}

In each experiment, three pieces (approximately $80 \mathrm{mg}$ ) of isolated callus tissue were placed on solid medium. The location of each piece of tissue was standardized $(4 \mathrm{~cm})$ between pieces (Fig. 1). All tissues were incubated at $27 \pm 1^{\circ} \mathrm{C}$ in the dark for at least 3 weeks. The initial and final fresh weights were determined in sterile, tared, plastic Petri-dishes and the growth index (G. I.= final fresh weight/initial fresh weight) was calculated. The callus tissues vere removed from the medium after the growth period and the medium was assayed for the presence of growth regulators. Bacteria (Escherishie coli, Bacillus subtilis or Sarcina lutea), used in the initial assay, were maintained in $250 \mathrm{ml}$ flasks in shake cultures in standard rutrient broth (Baltimore Biological Laboratory) in the dark. Chlore 1 a sorokiniana, used in later bioassays, was obtained from Dr. E. Karlander, Department of Botany, University of Maryland. Chlorella cells were grown on a shaker in liquid 23 medium supplied with $0.1 \%$ yeast extract and $0.1 \%$ bacterial peptone. Microorganisms used in the bioassays were flooded over the surface of solid medium which had supported the growth of callus tissue. The excess inoculum was removed by tipping the plates and blotting off the excess suspension and the plates incubated either in the dark or in the Iight on a 14-hour photoperiod (Ch1ore11a). Bioassay plates were incubated at $27 \pm 1{ }^{\circ} \mathrm{C}$ for three days or until the test organisms produced sufficient growth. The diameters of inhibitory zones were measured and employed as an index of the relative strength of growth regula- 


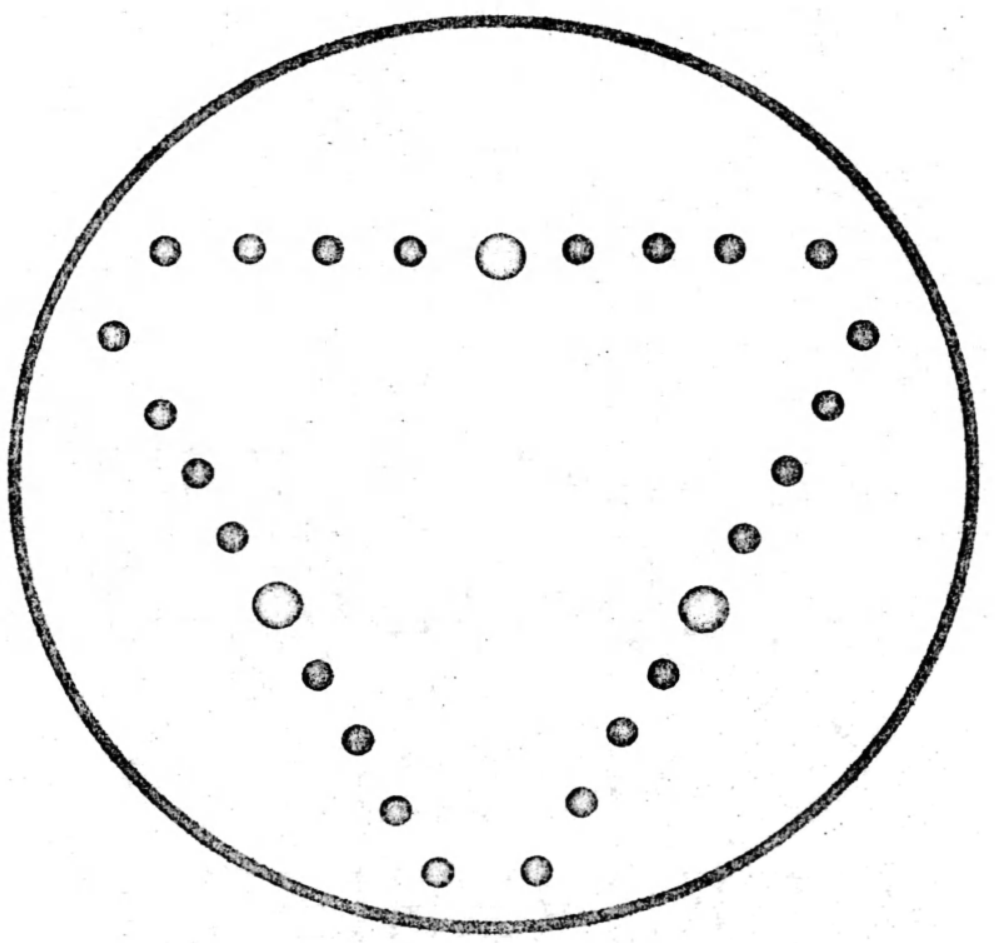

FIGURE 1. ARRANGEMENT OF TOMATO SEEDS OR LEMNA PLANTLETS DURING BIOASSAY FOR GROWTH REGULATORS

Large dots indicate the position of callus tissue prior to removal for assay. Small dots indicate the position of tomato seeds or Lemna plantlets. 
tion.

Seeds used in the tomato bioassay were surface sterilized according to the procedure outlined for stem sections. Sterile tomato seeds were placed on solid medium which had supported the growth of callus tissue and arranged in a standard pattern (Fig. 1) with 0.7 $\mathrm{cm}$ between each seed. Twenty four tomato seeds were placed pn each plate and incubated in the dark at $27 \pm 1^{\circ} \mathrm{C}$. The percent seed germination was calculated daily and used as an index of the presence of growth regulatory materials. The tomato seedlings were also observed and deviations from the growth and development of control seeds were noted. The final fresh weight of the tomato seedlings on each plate was also recorded.

Actively growing sterile Lemna minor plants with two fronds each, were also used as an assay system. Stock cultures of Lemma were maintained on solid 23 medium in the light on a 14-hour photoperiod. The plants were placed on the culture medium and incubated in the light according to the procedure outlined in the tomato bioassay. The daily rate of increase in frond number and frond area were used as criteria for the presence of growth regulators in the medium. Frond area per plate was determined using an overhead projector at a standard distance from a screen with an image of the fronds projected and traced on paper. Frond area was determined by cutting out the images, weighing the paper and calculating the area using standard weightarea factor for the paper. The total frond area per plate was recorded in the beginning and at the end of each experiment and used to calculate the frond-area index (final frond area/initial frond area). 
Stem sections were used to detect regulators which influence cell division and elongation. Alaska peas, used in this bioassay, were soaked in distilled water for two hours and grown in vermiculite at $22 \pm 1^{\circ} \mathrm{C}$ in the dark for 7-8 days according to the procedure outlined by Galston and Hand (1949). Epicotyl section (10 mm) were cut under a red safety 1ight, just below the hook of the pea seedlings. A total of 18 epicotyls were placed on each plate and arranged as in Figure 1 with three epicotyls on each side of the position where the tissue had grown. Treatment and control plates were incubated at $22+1^{\circ} \mathrm{C}$ in the dark and the length of the epicotyls was measured after 24 hours.

The influence of the secretion of one callus tissue on another explant was investigated to further characterize the secretion of regulatory materials into the culture medium. A standard tissue (sugar maple root callus tissue) which did not secret detectable stimlatory or inhibitory materials, was used to detect the presence of nitelabolites secreted by the test tissue. A piece of standard callus tissue (approximately $200 \mathrm{mg}$ ) was placed at the center of the Petri plate and four pieces (each approximately $100 \mathrm{mg}$ ) of the test tissue were equally spaced at a distance of $2.5 \mathrm{~cm}$ from the assay tissue. Control plates containing only standard tissue were included in each experiment. Additional control plates containing only one piece of standard tissue at the center of the plate were set up to determine the possible influence of the depletion of nutrients. Al1. tissues were incubated at $27 \pm 1{ }^{\circ} \mathrm{C}$ in the dark for at least three weeks and the growth index was calculated for assay and standard tissues. 
TISSUE EXTRACTS

Sweet potato (Ipomoea batatus) tubers were sprouted in a beaker and transfered to 8-1iter buckets containing a standard hydroponic solution (Appendix, Table 3) and grown in the greenhouse. Small (3 ft.) black locust (Robiania pseudoacacia) trees were obtained from the field and also transfered to hydroponic cultures. Five plants were placed in each bucket and water was added as needed during the four-month culture period. At the end of the culture period, transpiration of the plant had reduced the volume of the culture medium to approximately $100 \mathrm{ml}$. This solution was passed through a millipore filter (Milipore Filter Corporation G. S. 0.22u) and used in the bioassays. Two-tenths $\mathrm{m} 1$ of this solution was added to a sterilized stainless steel cylinder (penicylinder $1 \mathrm{~cm} \times 0.7 \mathrm{~cm}$ ) which was placed at the center of the plate. The solution was allowed to diffuse into the surrounding medium (3 days) and the medium was assayed for the presence of growth regulatory substances in the concentrated exudates.

Juice expressed from isolated callus tissue was also assayed using the penicylinder method. Callus tissues which had either stimulatory or inhibitory effects in previous bioassays were extracted either with distilled water or ethyl ether. Twenty grams of callus tissue were placed in a mortar with $40 \mathrm{ml}$ of distilled water and ground for 5 minutes. The slurry was filtered through a Whatman No. 3 filter paper and the residue was washed three times with $20 \mathrm{~m} 1$ portions of distilled water and reduced in vacuo at $50^{\circ} \mathrm{C}$ to a volume of $5 \mathrm{ml}$ (W extract). Ethyl ether extracts were obtained using the same procedure except the in vacuo temperature was $30^{\circ} \mathrm{C}$ and the extracts were 
reduced to dryness. This residue was extracted with $5 \mathrm{ml}$ of distilled water (EW extract). The residue, after water extraction, was taken up in $5 \mathrm{ml}$ of ethyl ether (EWE extract). The W, EW and EWE extracts were passed through a millipore filter and bioassayed using the penicylinder method. 


\section{RESULTS AND DISCUSSION}

\section{TISSUE STERILIZATION}

The initial portion of this study concerned the sterilization of tissue from a wide variety of plants. Forty-two different plant species (Appendix, Table 4) were used to obtain a total of 32 sterile tissues. A number of plant materials could not be sterilized by increasing the sterilization time or varying the concentrations of sterilization solution. The surface (texture, etc.) of the tissue and the possibility of endogenous microorganisms were factors in the efficiency of the sterilization process. Twenty-seven of the 32 sterile tissues produced callus on the medium employed in this study while trelve of the tissues grew rapidly and produced a relatively large amount of isolated callus tissue.

Fach of the sterilized plant sections was transfered to three media-IK, 2,4-D and 23 medium (Appendix, Table 1 and 2). The rate of production of stem callus tissue was relatively slow when compared to the proliferation of callus tissue after isolation. Certain species produced callus which grew rapidly on one kind of medium but not on other media while other tissues grew well on all media (Table 1 ). Murashige and Skoog (1962) suggested that the callus tissues from a11 plants have similar nutrient requirements but often their growth is limited by one of a few comnon growth factors, suchas auxin. They also suggested that tissues from different parts of the same plant may have different quantitative nutrient requirements for optimaI growth in vitro. The isolated callus tissue of blue flower chicory 
Table 1

THE GROWTH OF ISOLATED CALLUS ON SELECTED MEDIA

Scientific Name (1)

Prunus persica

Lonicera japonica

Solidago canadensis

Amelanchier alnifolia

Salix a1ba

Morus rubra

Rramus cathartica

Syringa vulgaris

Robinia pseudoacacia

Ipomoea purpurea

Rosa virginiana

Phytolacca americana

Ginkgo biloba

Liquidambax styraciflua

Populus alba

Ilex opaca

Acer negundo

Juglans nigra

Gossypium herbaceum

Sambucus canadensis

Betula alba

Solanum americanum
Source of

Tissue

stem (2)

stem

stem

stem

stem

stem

stem

stem

stem

stem

stem

stem

stem

stem

stem

stem

stem

fruit

petiole

stem

stem

fruit $\begin{array}{ccc}\text { Rate of Callus } & \text { Production } \\ 23 & \text { IK } & 2,4-D\end{array}$

$\begin{array}{ll}+ & + \\ + & ++1\end{array}$

$+\quad+$

$+\quad+t$

$+\quad \pm \quad+$

$++t$

$+H+t$

$\pm \quad \pm \quad+$

$++t+1+$

$+\quad+\quad+++$

$+\quad+\quad-$

H H H H

$+H+H$

$+\quad+\quad+$

$+\quad+\quad+$

$\pm \quad \pm \quad+$

$+\quad++$

$+\quad-\quad+$

$+\quad+$

$+H+H$

$H+H$

$+H+H$ 
Table 1 (continued)

\begin{tabular}{|c|c|c|c|c|}
\hline Scientific Name ${ }^{(1)}$ & $\begin{array}{l}\text { Source of } \\
\text { Tissue }\end{array}$ & $\begin{array}{l}\text { Rate of } \\
23\end{array}$ & $\begin{array}{l}\text { Callus } \\
\text { IK }\end{array}$ & $\begin{array}{l}\text { Production } \\
\quad 2,4-D\end{array}$ \\
\hline Pyrus malus & stem $^{(2)}$ & ++ & $H$ & + \\
\hline Cichorium intybus & stem & + & + & $H$ \\
\hline$\frac{\text { Brassica }}{\text { var. capitata L. }}$ & $\begin{array}{l}\text { stem } \\
\text { (pith) }\end{array}$ & $\dot{+}$ & + & ++ \\
\hline$\frac{\text { Brassica oleracea }}{\text { var. botrytis L. }}$ & $\begin{array}{l}\text { stem } \\
\text { (pith) }\end{array}$ & + & + & + \\
\hline Lactuca sativa & $\begin{array}{c}\text { stem } \\
\text { (pith) }\end{array}$ & + & + & + \\
\hline
\end{tabular}

(1) for common names see Appendix Table 4.

(2) callus tissue from stem cambial area.

(3) subsequent transfers were made to the medium which supported the most rapid tissue growth. H indicates satisfactory growth. 
(Cichorium intybus), elderberry (Sambucus canadensis), honeysuckle (Lonicera japonica) and pokeberry (Phytolacca americana) produced a few roots and blue flower chicory tissue produced a shoot when the tissues were cultured in IK medium. Differentiation in these tissues was inhibited by transferring the isolated callus to either 23 or $2,4-D$ medium. Certain callus tissues (pokeberry and morning glory, Ipomoea purpurea) also required an adaptation period of slow growth which was followed by rapid tissue growth. Other tissues (black locust, Robinia pseudoacacia, and ginkgo, Ginkgo biloba) grew rapidly and then with time, grew slowly. In the former case, a lag period may be required for the formation of adaptive enzymes and in the latter instance a critical growth factor may be lacking. Many isolated callus tissues were ijght colored when actively growing and brown when growing slowly. The presence of brown coloration suggests the aging of the cel1s and the possible oxidation of simple phenolic compounds. ActiveIy growing tissues were used in the bioassays.

DETECTION OF GROWTH REGULATORS

Bacteria were used to assay for the secretion of growth regulators by 20 isolated callus tissues. The isolated callus tissues used in this series of assays were sweet potato (Ipomoea batatus), carrot (Daucus carota), plantain (Plantago ovata), tobacco (Nicotiana tobacum), triploid aspen (Populus tremuloides), peach (Prunus persica), serviceberry (Amelanchier alnifolia), black locust (Robinia pseudoacacia), morning glory (Ipomoea purpurea), pokeberry (Phytolacca americana), ginkgo (Ginkgo biloba), box elder (Acer negundo), black walnut (Juglans nigra), elderberry (Sambucus canadensis), blue flower chicory (Cichorium 
intybus), white potato (Solanum tuberosum), sugar maple (Acer saccharum), cabbage (Brassica oleracea var. botrytis), cauliflower (Brassica oleracea var. capitata L.) and lettuce (Lactuca sativa). Stimulation or in-

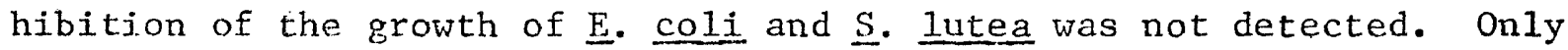
four out of the 20 callus tissues (aspen-Figure 2, pokeberry, serviceberry, and sweet potato) were found to have antimicrobial activity against $\underline{B}$. subtilis (Table 2). Stimulatory influence on the growth of B. Subtilis was not observed. Nicke11 (1960) listed references which reported antimicrobial activity in extracts from pokeberry, serviceberry and sweet potato. The possibility of the secretion of inhibitors into the culture medium by isolated callus tissues was not explored in thjs review. The intact plants of peach, morning glory, black walnut, cauliflower, cabbage, sugar maple, carrot, black locust, elderberry and white potato were also listed for antinicrobial activity by Nickell (1.960). Ginkgo was reported to have antimicrobial activity. by Major (1967). Callus tissues isolated from the plants listed by Nickell and Major did not produce inhibitory zones against the bacteria employed in this bioassay. More than half (Mathes 1967-65\%, Khanna and Stabe 1968-90\%) of the isolated callus tissues studied have been reported to have antimicrobial activity. In my assays, on $1 \mathrm{y} 20 \%$ of the isolated callus tissues studied showed antimicrobial activity using B. subtilis. The report (Mathes 1967) that the callus tissue from sweet potato and aspen possess antimicrobial activity against B. Subtilis was substantiated in this investigation. My results also confirm the work of Mathes (1967) who indicated that the explants of carrot, ginkgo, white potato, plantain and sugar maple do not have antimicrobial activity in vitro. The ginkgo callus tissue used by 


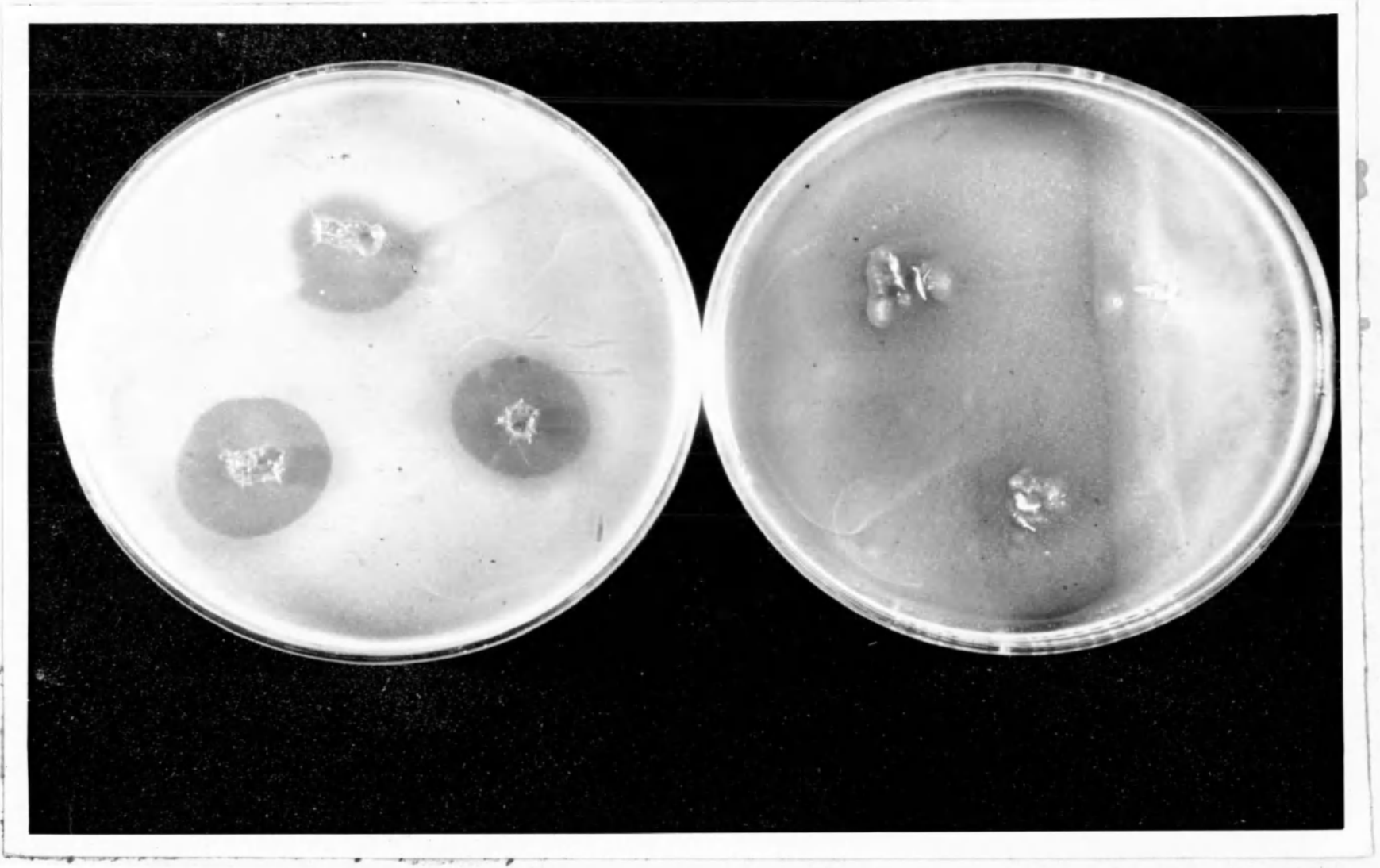

FIGTRE 2. ThE INHIBITTON OF THE GROWTH OF BaCiIIUS SUbLIIIS IN WHE PRESRME OF SECRETTONS OF ASPEN CAILUS TISSUE The contiol plate in the absence of tissue is shown on the ris. 35.4 


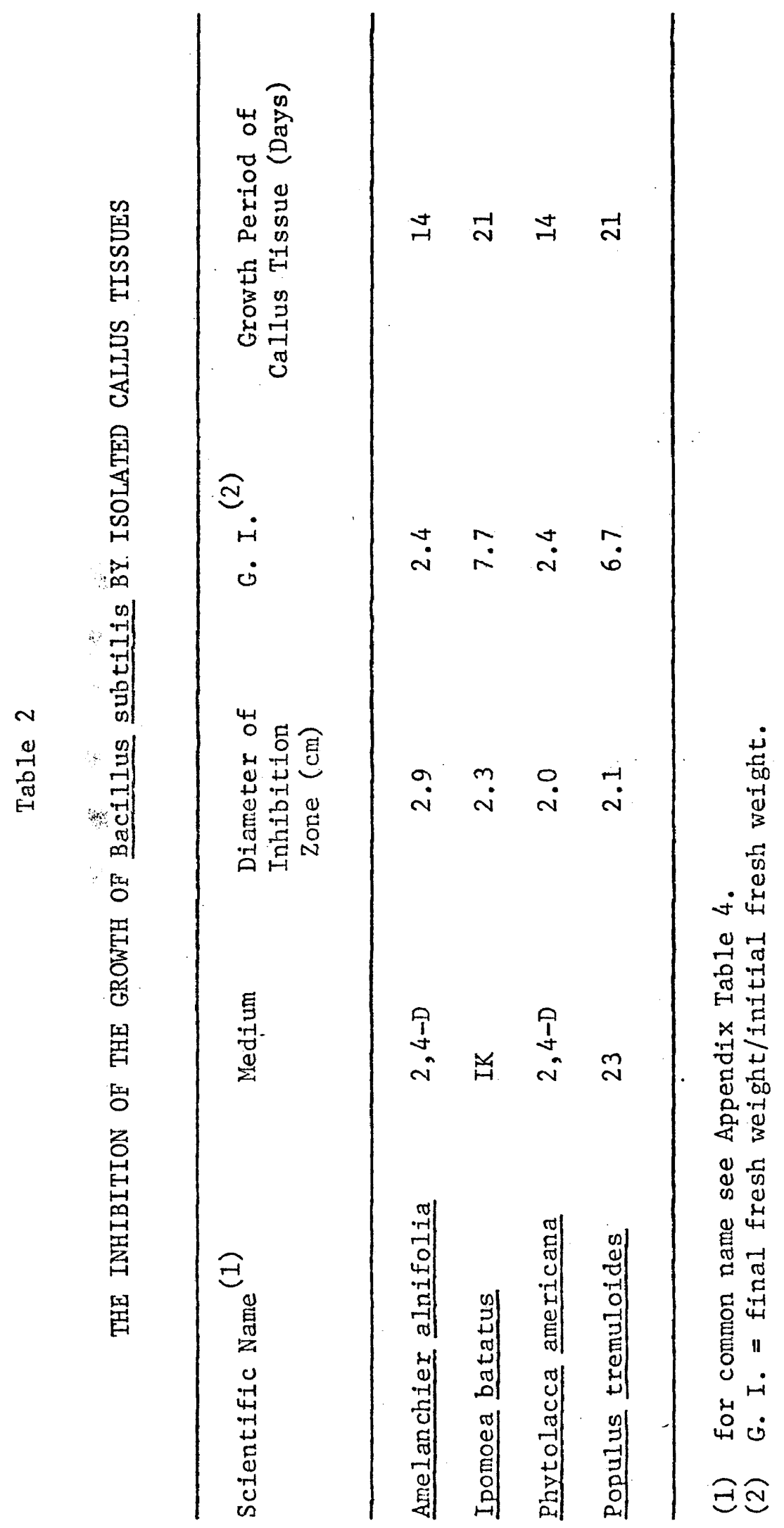


Mathes (1967) was isolated from the pollen while the callus tissue used in this study was isolated from a long stem. Khanna and Staba (1968) reported that callus tissue and extracts isolated from tobacco has antimicrobial activity against Staphylococcus aereus and E. coli. In these experiments, inhibited bacteria growth was not detected using isolated tobacco callus tissue. This lack of confirmation may be due to tissue differences or the result of using a different strain of E. coli. Campbel1 et a1. (1965) reported that callus tissues from lettuce and cauliflower secrete materials that have antimicrobial activity (E. 이고 and $\underline{B}$. cereus). In this investigation, antimicrobial activity against $\underline{E}$. $\underline{\text { coli }}$ and $\underline{B}$. subtilis was not detected after the growth of lettuce or cauliflower callus tissues. Antibiotics may have a very narrow spectrum of antimicrobial activity as suggested by Campbell et al. (1965), and callus tissues grown on different media and under different conditions may also have a different type of metabolism and may secrete different kinds of metabolites. The information provided by these experiments suggests that isolated callus tissue secrete metabolites which differ from the materials present in the intact plants. This type of comparison has not been previously reported.

The use of Lenma as an assay organism to detect growth regulators was employed by Gorham (1941) and others. An aseptic method for measuring the frond area of Lemna was developed in this study. The number of fronds and the frond area increment were used as an index of the growth of Lemnia on 3 medja. The most rapid growth of Lemna occurs on 23 medium while the growth on IK or 2,4-D medium is relatively slow and epinasty was observed. The influence of auxin on the epinastic response of Lemnia has been reported by Gorham (1941). Seven callus tissues 
(ginkgo, serviceberry, aspen,-Figure 3, sweet potato, blue flower chicory, pokeberry and lettuce) were found to have an inhibitory effect on the growth of Lemna. Table 3 shows the relative strength of inhibition of the growth of Lemna by the secretions of different callus tissues and Figures 4, 5 and 6 show the progressive inhibition after the growth of aspen, serviceberry or pokeberry callus tissues. The tissue with the greatest amount tissue present (sweet potato) or the most rapid rate of tissue growth did not produce the largest amount of inhibition in the Lemna test. These observed differences in the strength of Lemna inhibition by various tissues cannot be explained simply by different amounts of tissue present or the rate of tissue growth but must also involve differences in the amount of material secreted or in the strength of the inhibitors. The stimulation of Lemna growth was not detected. A shift in the acidity of the medium could result in a decreased rate of Lemna growth. The hydrogen ion concentration of the media after tissue growth was found (Appendix, Table 5) to range from 4.9 to 6.0. This pH raxge was not sufficient to significantly modify the growth of the assay organisms since it falls within the optimal range $(4.5-7.5)$ for the growth of Lemna (Hicks 1937). The inhibition of Lema growth may also result from depletion of the nutrients by isolated callus tissues. A nutrient solution was flooded over the surface of the culture medium after the growth of certain non-inhibitory isolated callus tissues. The results showed there was no difference in the growth of Lemna when the nutrient level was supplemented. It can be concluded from these experiments that a growth inhibitor(s) of Lemna growth was secreted by certain isolated callus tissues.

Tomato seed germination and seedling growth were also used to detect 


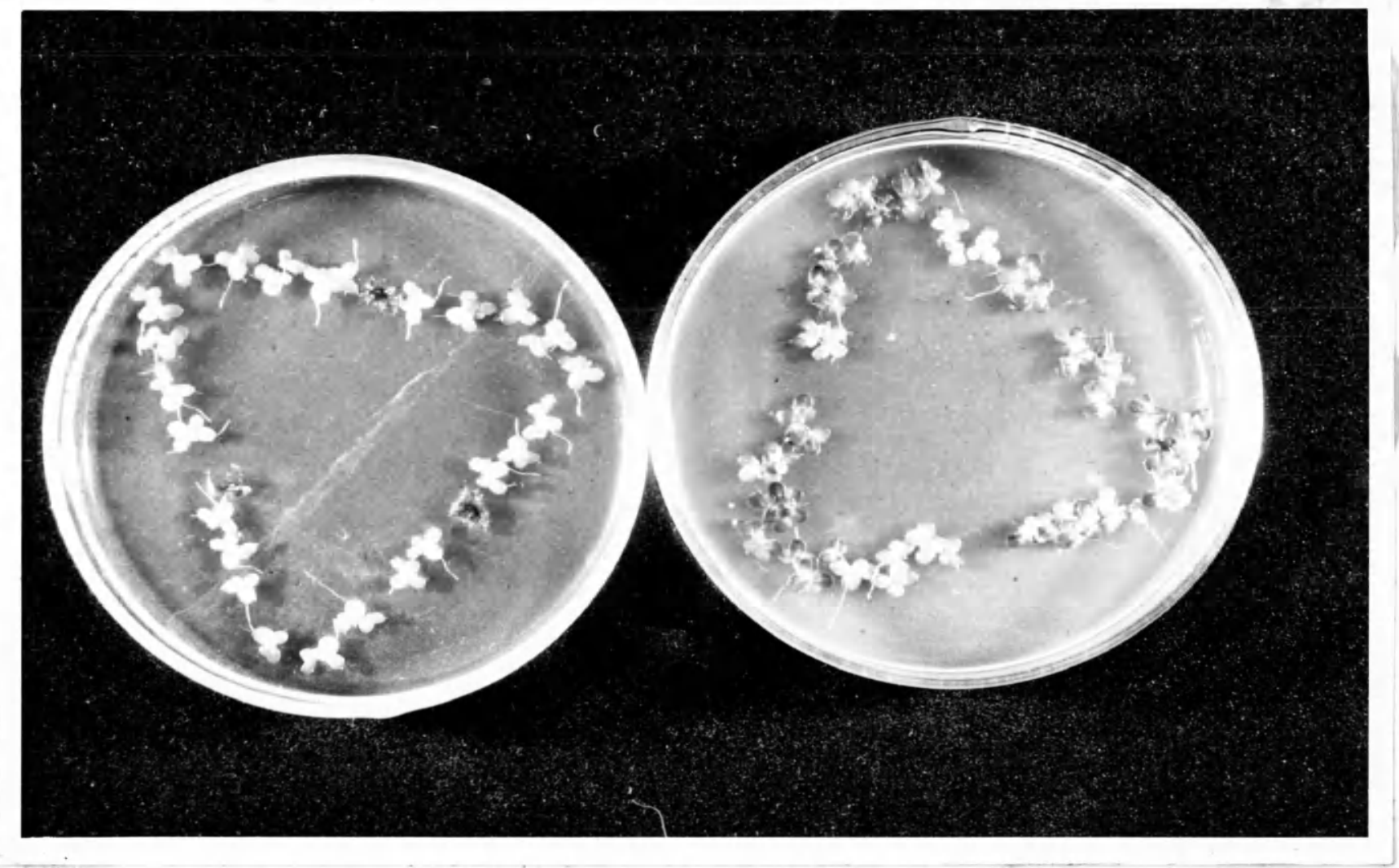

FIGURE 3. THE GRONTI OF IEMAN mJ ROX IN THE PRESEROE OF SECRETTONS FROM ASTIN CATUUS TESUE

The control plate in the absence of tissue is shown on the right. 


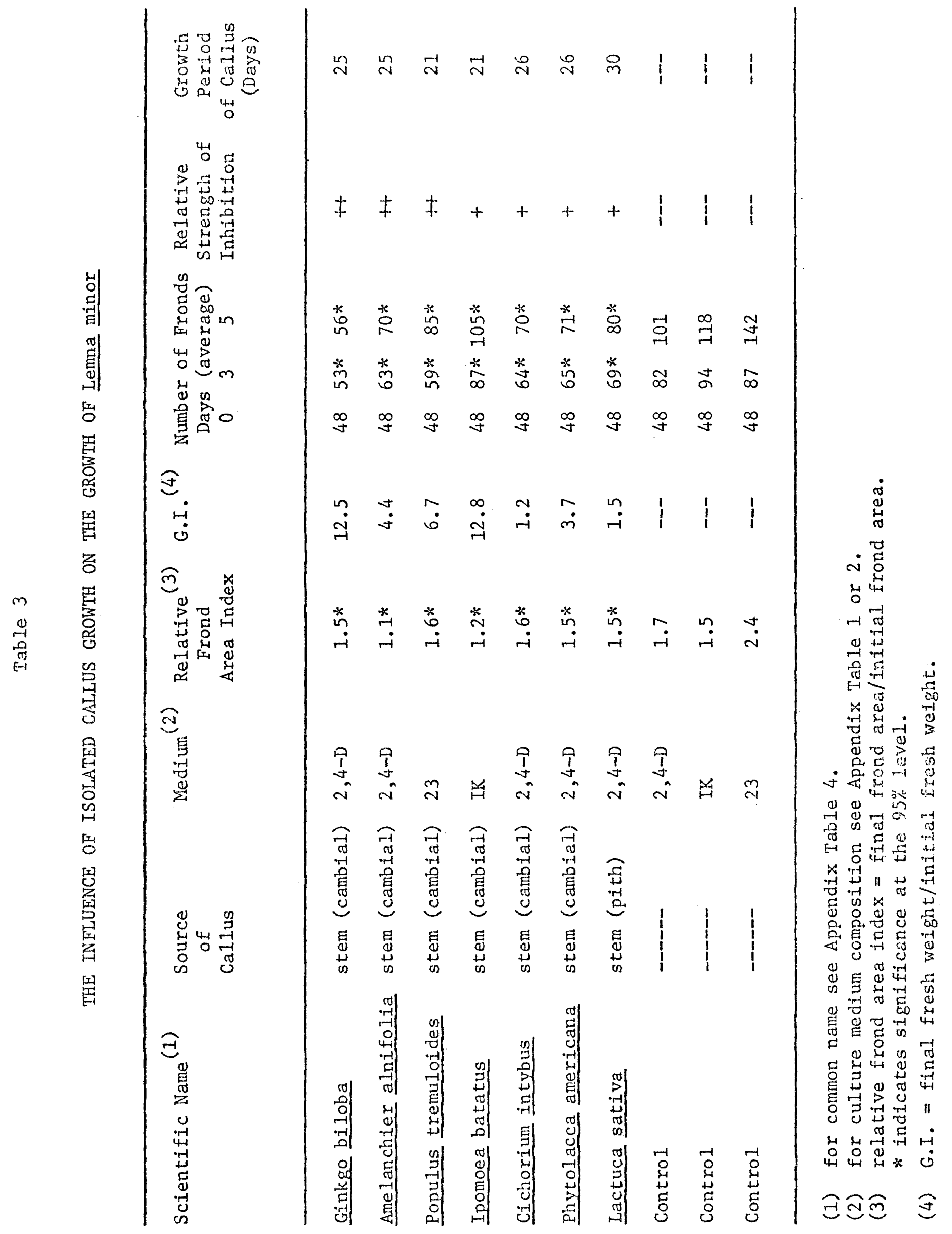




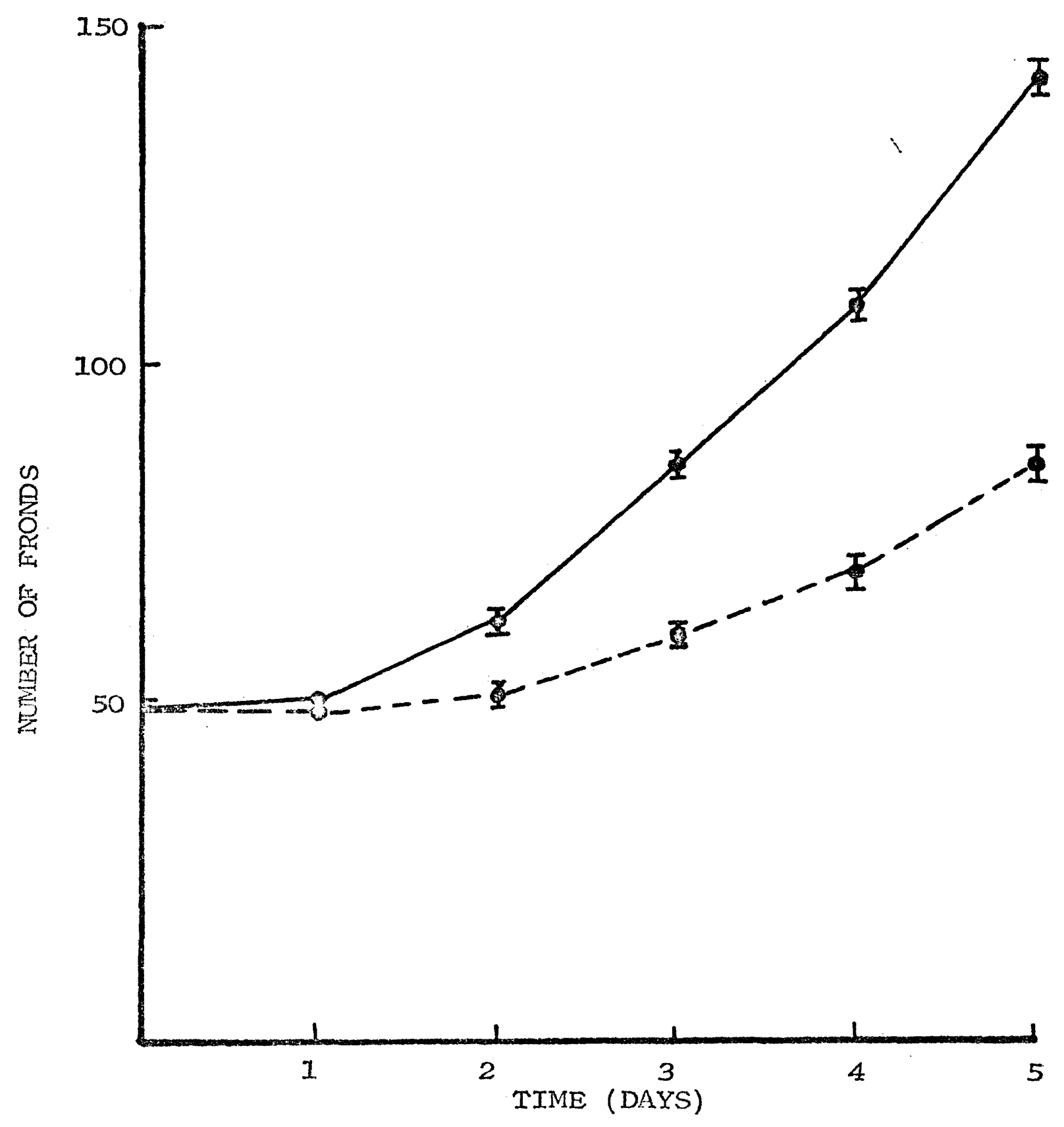

FIGURE 4. THE GROWTH OF LEMNA IN THE PRESENCE OF MATERTAIS SECRETED BY ISOLATED ASPEN CALLUS TISSUE control aspen tissue $\ldots \ldots-m-n$

$I$ - indicates $95 \%$ significant level 


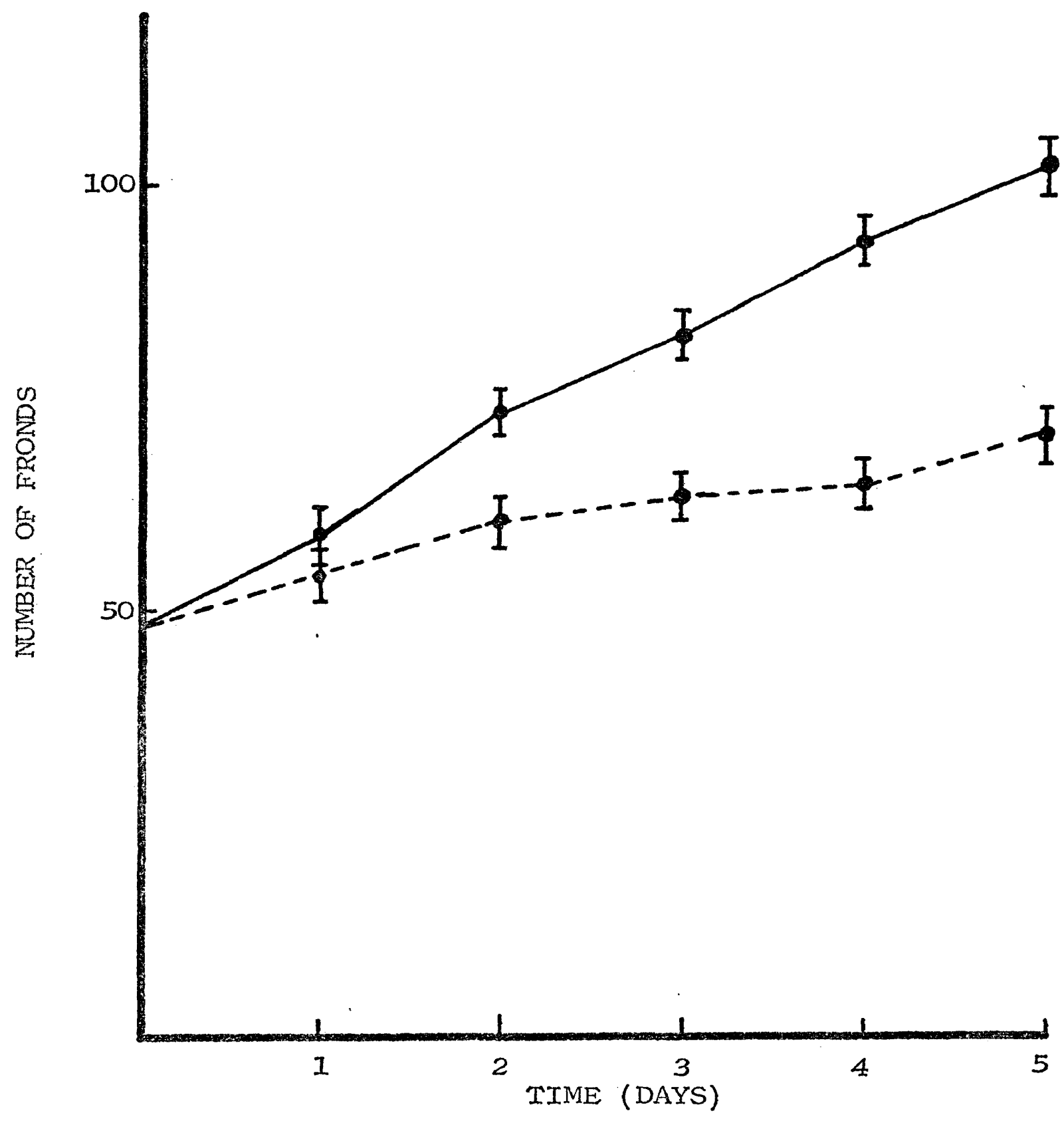

FIGURE 5. THE GROWTH OF LEMNA IN THE PRESENCE OF MATERIALS SECRETED BY ISOLA'TED SERVICEBERRY CALIUS TISSUE control

serviceberry -m-n-m

$\Phi$ - indicates $95 \%$ significant level. 


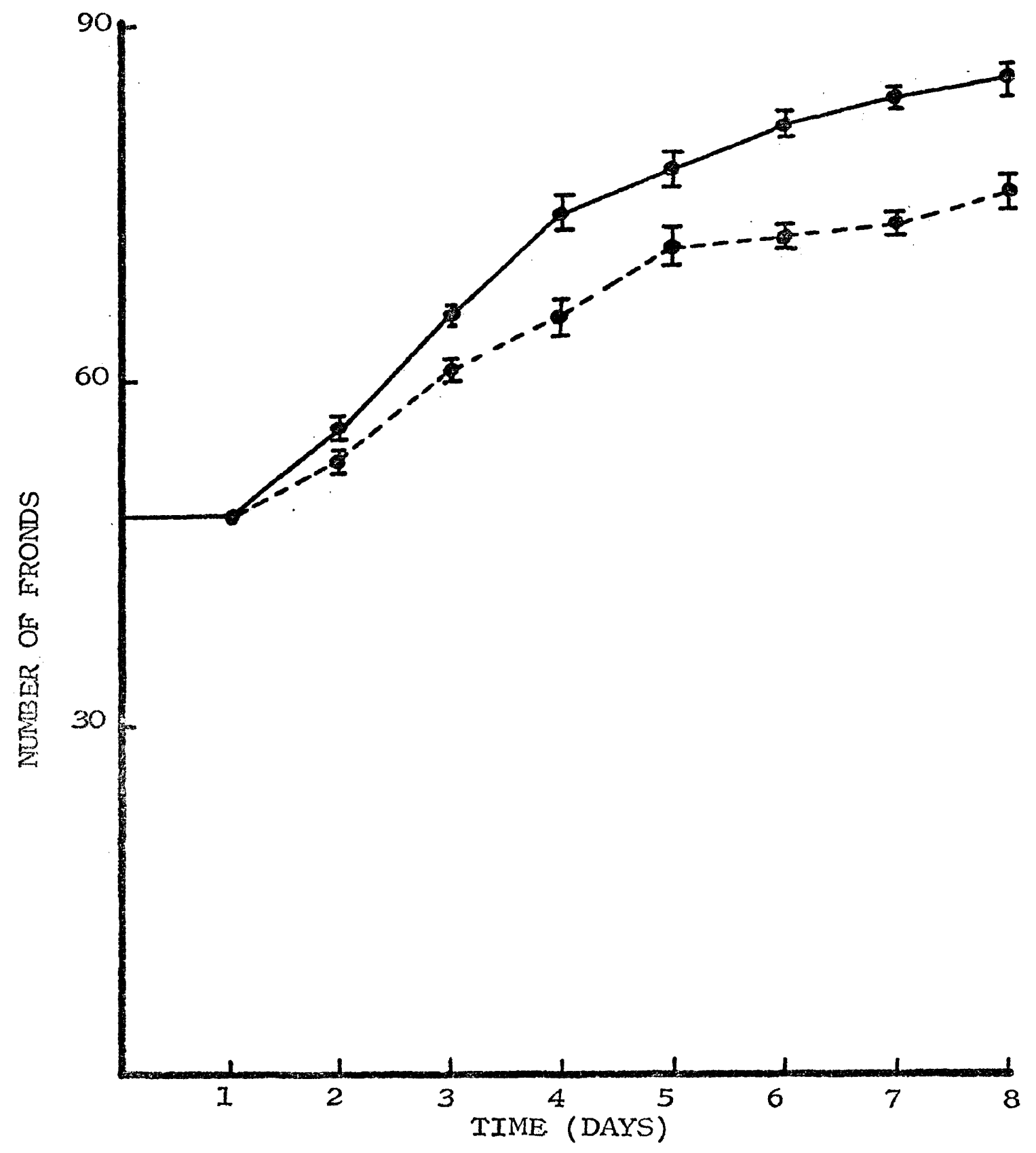

FIGURE 6. THE GROWTH OF LEMTA IN THE PRESENCE OF MATERIALS SECREIED BY ISOTATED POKEBERRY CALLUS TISSUE control pokeberry callus tissue -.m.nF - indicates $95 \%$ significant level 
growth regulators produced by the same 20 isolated callus tissues employed in the bacterial assay. Tomato seed germination inhibitors were found in the culture medium used to support the growth of morning glory, serviceberry, box elder, plantain, ginkgo, peach-Figure 7 and lettuce explants. A stimulator was observed in the secretion of sweet potato and white potato explants. Table 4 shows the inhibitory or stimulatory effect of the secretions of callus tissues on the germination of tomato seeds. Figures 8,9 and 10 show the different rates of tomato seed germination as influenced by selected explants. The growth of seedlings was most rapid on IK medium with an occasional epinastic bending of the seedlings. The hydrogen ion concentration of the media after tissue growth was measured prior to the germination of tomato seeds. Although the $\mathrm{pH}$ of the media varied from 4.9 to 6.0 (Appendix, Table 5), it did not have a significant effect on the germination of tomato seeds. There were no detectable growth regulators of tomato seedling growth (after germination) present in the secretions of isolated callus tissues. Carly and Watson (1968) reported that an aqueous extract of white potato will strongly inhibit the germination of clover, lettuce, radish and wheat seeds. Steward and Caplin (1952) showed that extracts of white potato tubers contained substances which inhibit the growth of carrot tissue in vitro while Barker (1970) reported that the secretion of white potato explants will stimulate the growth of carrot in vitro. Black walnut trees have been shown to have an allelopathic effect on the growth of tomato plants (Cook 1921, Massey 1925, Schneiderham 1927 and Davis 1928). In my experiments, inhibitory substances which reduce the germination and subsequent growth of tomato seeds were not detected in black walnut callus tissue secretions. 


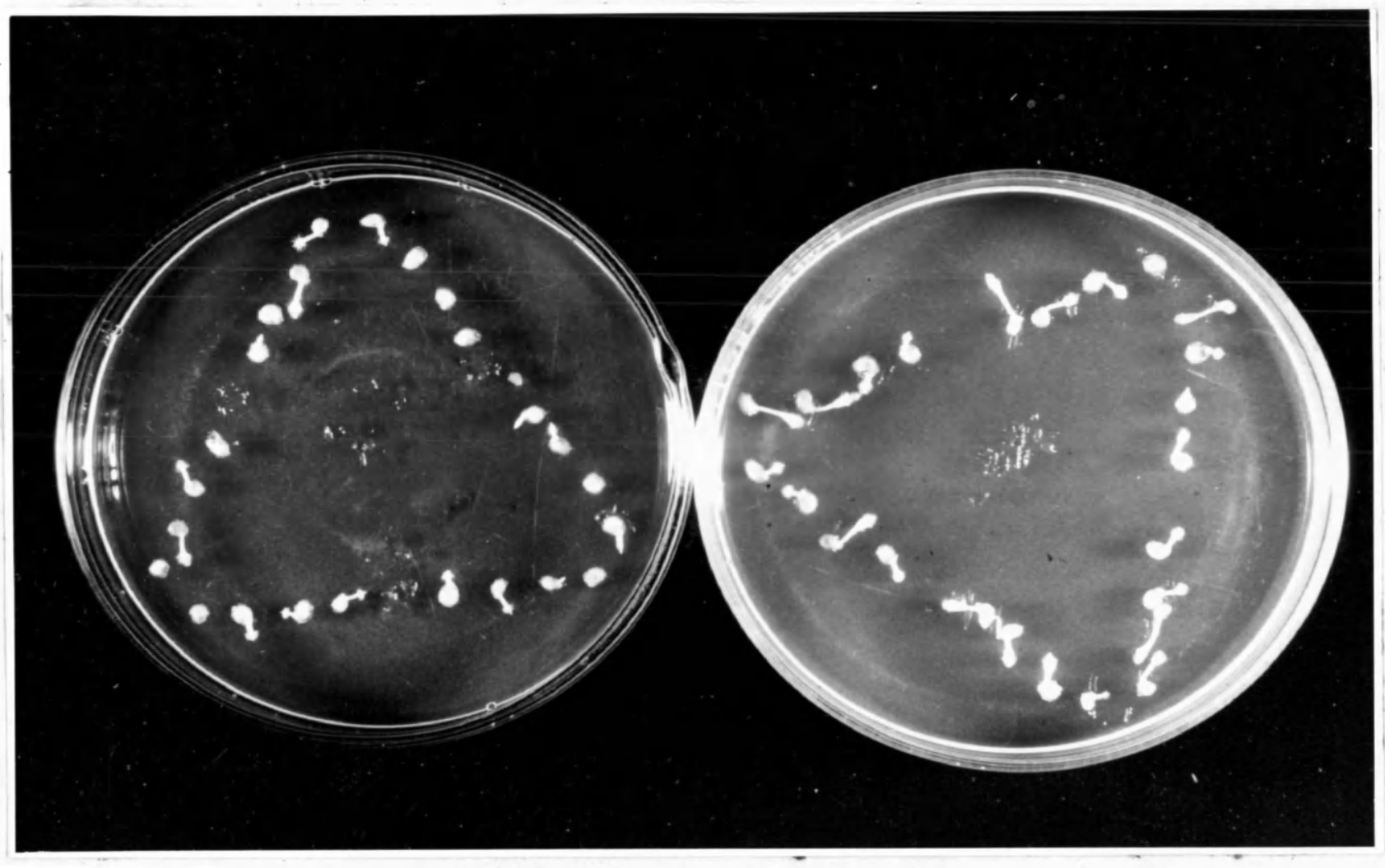

FIGURE 7. THE GERMINATJON OF TOMATO SEEDS TN THE PRESENCE OF SECRETLONS FROM ISOLATED PEACH CALLUS TTSSUE

The control plate in the absence or tissur is shown on the right. 
Table 4

THE INFLUENCE OF ISOLATED CALLUS GROWTH ON THE GERMINATION AND GROWTH OF TOMATO SEEDS

\begin{tabular}{|c|c|c|c|c|c|}
\hline $\begin{array}{l}\text { Scientific } \\
\text { Name }\end{array}$ & $\begin{array}{l}\text { Source } \\
\text { of } \\
\text { Callus }\end{array}$ & Medium $(2)$ & G. I. (3) & $\begin{array}{c}\text { Relative } \\
\text { Germination } \\
\text { afte }(4) \\
5 \text { days }\end{array}$ & $\begin{array}{l}\text { Growth } \\
\text { Period of } \\
\text { Callus } \\
\text { Tissue }\end{array}$ \\
\hline$\frac{\text { Anelanchier }}{\text { Alnifolia }}$ & $\begin{array}{l}\text { stem } \\
\text { (Cambial) }\end{array}$ & $2,4 \mathrm{D}$ & 4.4 & $78 *$ & 25 days \\
\hline$\frac{\text { Ipomoea }}{\text { purpurea }}$ & $\begin{array}{l}\text { stem } \\
\text { (cambia1) }\end{array}$ & $2,4 D$ & 3.2 & $76 *$ & 32 days \\
\hline $\begin{array}{l}\text { Acer } \\
\text { negundo }\end{array}$ & $\begin{array}{l}\text { stem } \\
\text { (cambia1) }\end{array}$ & 2,40 & 1.1 & $89 *$ & 26 days \\
\hline$\frac{\text { P1antago }}{\text { ovata }}$ & $\begin{array}{l}\text { stem } \\
\text { (cambia1) }\end{array}$ & 23 & 2.1 & $83 *$ & 21 days \\
\hline$\frac{\text { Ginligo }}{\text { biloba }}$ & $\begin{array}{l}\text { stem } \\
\text { (cambia1) }\end{array}$ & 2,40 & 12.5 & $89 *$ & 25 days \\
\hline$\frac{\text { Pranus }}{\text { persica }}$ & $\begin{array}{l}\text { stem } \\
\text { (cambial) }\end{array}$ & $2,4 \mathrm{D}$ & 5.1 & $84 *$ & 25 days \\
\hline$\frac{\text { Lactucas }}{\text { sativa }}$ & $\begin{array}{l}\text { steni } \\
\text { (pith) }\end{array}$ & $2,4 \mathrm{D}$ & 1.5 & $62 \%$ & 39 days \\
\hline$\frac{\text { Ipomoea }}{\text { batatus }}$ & stem & IK & 16.0 & $119 *$ & 25 days \\
\hline$\frac{\text { Solanum }}{\text { tuberosum }}$ & tuber & IK & 2.2 & 115\# & 25 days \\
\hline
\end{tabular}

(1) for common name see Appendix Table 4.

(2) for culture medium composition see Appendix Table 1 or 2 .

(3) G. I. = final fresh weight/initial fresh weight.

(4) relative germination $=$ number of seeds germinated in treatment/number of seeds germinated in control x 100 . all values are expressed as percent of control.

* indicates significance at $95 \%$ level.

\# Indicates significance at $90 \% 1$ level. 


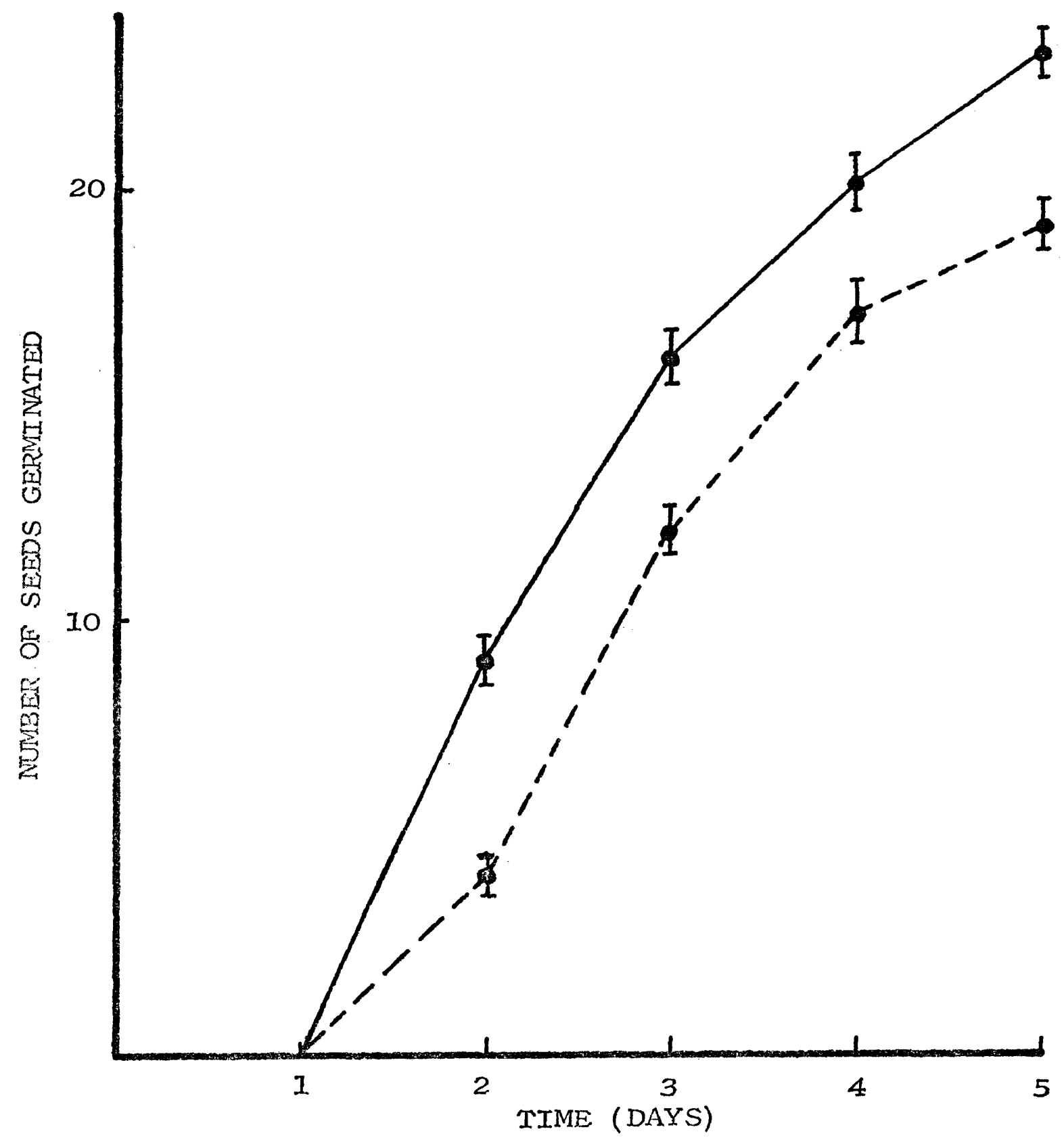

FIGURE 8. THE GERMINATION OF TOMATO SEEDS IN THE PRESENCE OF MATERIALS SECRETED BY ISOLATED PEACH CAILUS IISSUE control peach callus tissue -mmm-mI - indicates $95 \%$ significant level. 


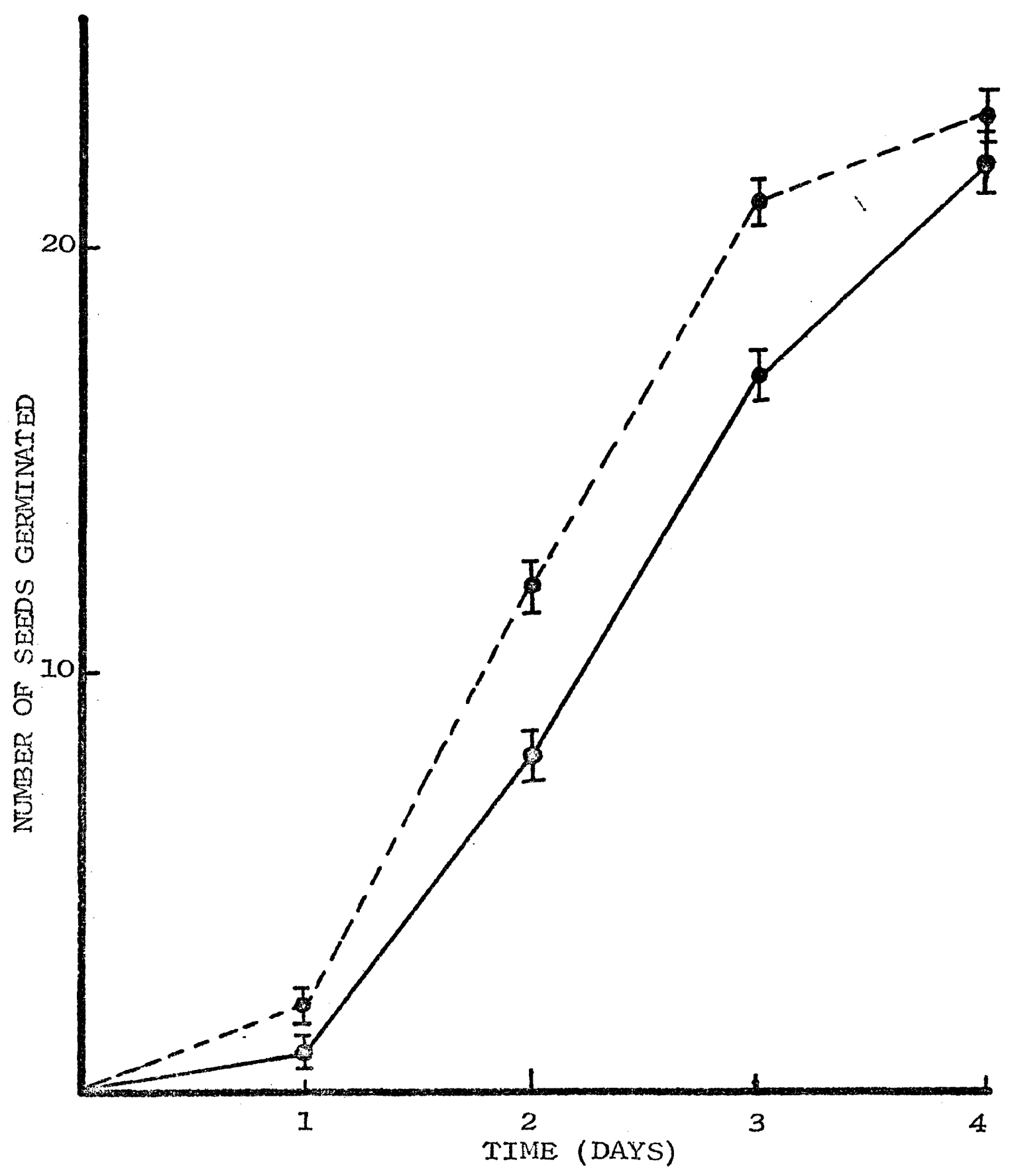

FIGURE 9. THE GERMINATION OF TOMATO SEEDS IN THE PRESENCE OF MATERIALS SECRETED BY ISOLATED SWEET POTATO CALLUS TISSUE control

sweet potato callus tissue -...-.-n

I - indicates $95 \%$ significant level 


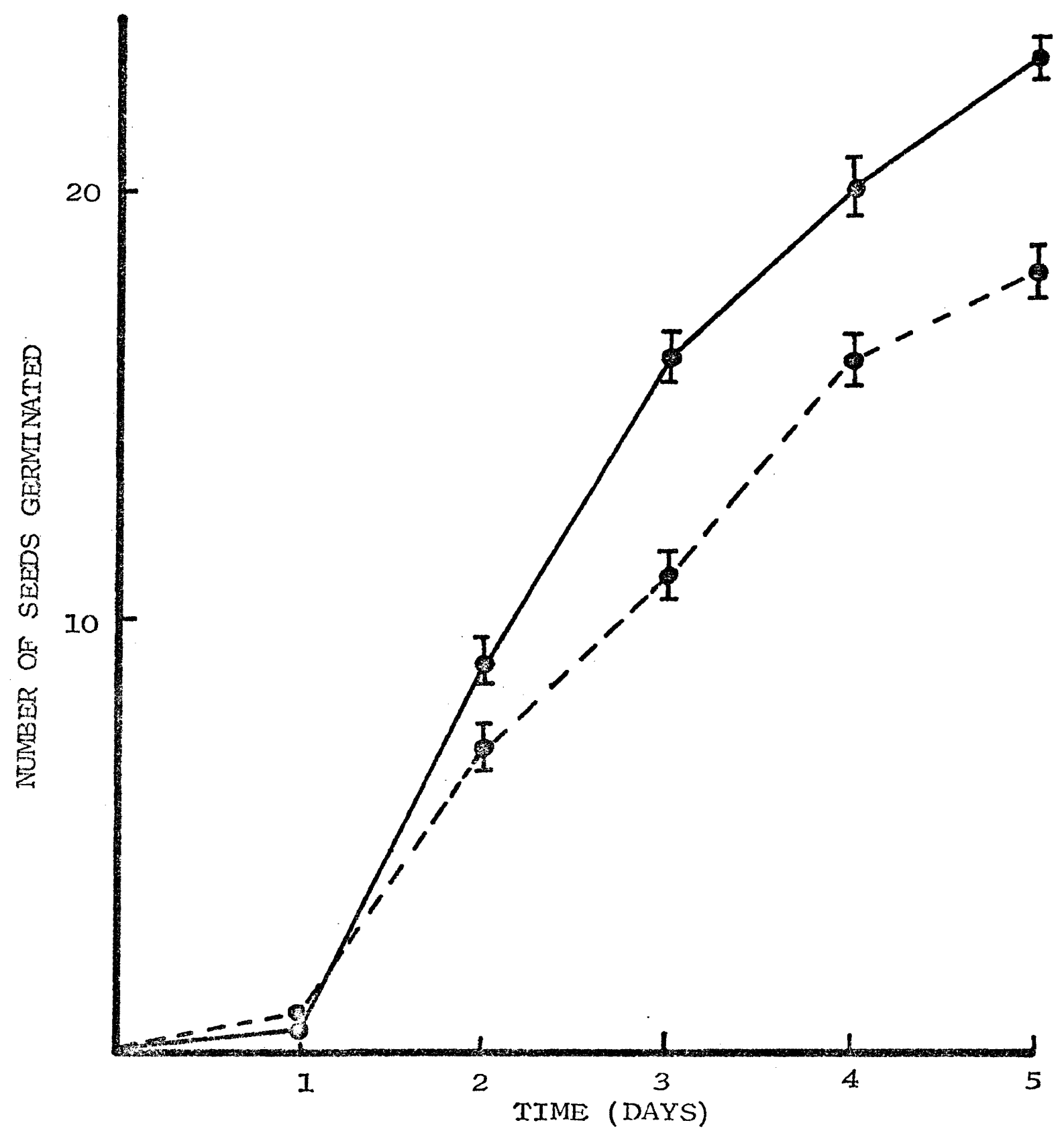

FIGURE 10. THE GERMTNATION OF TOMATO SEEDS IN THE PRESENCE OF MATERIALS SECRETED BY ISOLAIED SERVICEBERRY CAILUS TISSUE control serviceberry callus tissue -nn.m.n

1 - indicates $95 \%$ significant level 
The use of Chlore1la sorokiniana as an assay organism to detect growth inhibitors secreted by isolated callus tissues has not been reported prior to this study. Isolated tissues as used in the bacterial assays were employed in this study. Among those tissues, only aspen and pokeberry callus tissues produced materials which inhibited the growth of ChIorella. Stimulatory material was not detected. Aspen callus tissue was cultured for 23 days (G.I.=2.7) on 23 medium and pokeberry callus was cultured for 32 days (G.I.=5.4) before the assay. The average inhibitory zone was $2.4 \mathrm{~cm}$ for pokeberry callus tissue and $1.8 \mathrm{~cm}$ using aspen tissue. The $\mathrm{pH}$ of 23 medium which supported the growth of isolated callus tissues was found to be 5.6 for aspen and 5.2 for pokeberry tissues. The control medium had a $\mathrm{pH}$ of 5.8 (Appendix, Table 5). Chlorella grew well in a $\mathrm{pH}$ range greater than the $\mathrm{pH}$ variations obtained in the experiments and inhibitory zone were indicated by derreased growth in the area surrounding the callus tissues.

Barkex (1970) reported that the secretion of lettuce and cauliflower explants will stimulate the growth of carrot callus while white potato callus tissue is inhibited. Sugar maple root callus tissue was used as a standard callus tissue in the test of tissue interactions. This tissue was selected because of the rapid rate of growth and the absence of detectable growth regulator secretions. Callus tissues used in this test were the same as those used in the Chlorel1a assay. The growth of sugar maple root callus tissue was not influenced by the growth of other callus tissues on the same plate. An inhibition was found in the first assay of aspen tissue but the result could not be repeated in five subsequent tests.

Alaska pea epicotyls were employed in a straight growth test ac- 
cording to the method described by Galston and Hand (1949). IK and 2,4-D medium each containing $3 \%$ sucrose and 23 medium containing approximately $2 \%$ sucrose were used to support the growth of isolated tissues. These media exceed the maximum of sucrose concentration suggested for the elongation of pea epicotyls. It was therefore, impossible to detect inhibition as a result of tissue growth because elongation was inhibited by the sugar in the medium. Growth stimulators may, however, be detected. The isolated tissues did not influence pea epicotyl elongation.

The use of hydroponic methods to study the root exudates avoids the Jeaching and decomposition products of leaves. According to Rovira (1969) compounds with specific biological activity (stimulatory or inhibjtory) are exuded by plants in such small quantities that chemical and chromatographic techniques are not suitable. In these instances bioassay procedures must be used. Materials secreted in hydroponic cultures which stimulated or inhibjted tomato seed germination were not detected in the concentrated root exudates of sweet potato or black locust plants. The root exudates of sweet potato slightly inhibited the growth of Lemna. Additional activity was not detected using root exudates from sweet potato or black locust.

ISOLATION OF REGULATORY MATERIALS FROM CALLUS TISSUES

Callus tissues which had demonstrated in vitro activity in previous bioassays were used as a source of expressed juice in the penicylinder assay. The expressed juice of callus tissues from serviceberry, morning glory, box elder, plantain, ginkgo, peach, sweet potato or white potato was used to detect growth regulators in the tomato seed bioassay. 
Lettuce callus tissue did not grow rapidly and was therefore eliminated in this assay. Stimulatory or inhibitory influences on the germination of tomato seeds were not detected using expressed juice. The absence of activity may be the result of inactivation during the extraction process or the presence of very small undetectable amounts of regulators in the callus tissues. Callus tissues which were found to secrete materials which inhibited the growth of Lemna were also used as a source of expressed juice. The expressed juice of 6 species (Table 5) contained materials which inhibited the growth of Lemna minor. This assay indicated the presence of detectable levels of inhibitory materials In the callus tissues. Yeoman et al. (1967) has pointed out the occurrence of cellular autolysis in cultured callus tissues may be responsible for the diffusion of inhibitory materials into the medium. The expressed juice of aspen and pokeberry callus tissue also demonstrated a very slight inhibitory activity using Chlorel1a and aspen juice inhibited R. Subtilis. When $0.2 \mathrm{ml}$ of expressed aspen juice was used in the penicylinder method, an inhibitory zone with a diameter of $2.9 \mathrm{~cm}$ was obtained.

The callus tissues of sweet potato, peach, pokeberry and ginkgo because they grew very rapidly in the culture medium and produced a large amount of tissies, were extracted with solvents. The penicylinder method was used to determine the influence of these tissue extracts on the germination of tomato seed and the growth of Lema. Activity in the tonato seed assay was not detected using W, EW and EWE (see Material and Methods) extracts of the tissues. Table 6 shows the influence of tissue extracts on the growth of Lemna. The $W$ (Figure 11) and EW extracts of Ginkgo inhibited the growth of Lemna while the EWE 
Table 5

THE INFLUENCE OF JUICE EXPRESSED FROM ISOLATED CALLUS

TISSUES ON THE GROWTH OF Lemna minor

\begin{tabular}{|c|c|c|c|c|}
\hline \multirow[t]{2}{*}{$\begin{array}{l}\text { Scientific } \\
\text { Name }\end{array}$} & \multirow[t]{2}{*}{$\begin{array}{l}\text { Relative Frond } \\
\text { Area Index }\end{array}$} & \multicolumn{3}{|c|}{$\begin{array}{c}\text { Number of Fronds } \\
\text { Days }\end{array}$} \\
\hline & & 0 & 3 & 5 \\
\hline Amelanchier alnifolia & 4.0 & 32 & $65 *$ & $113 *$ \\
\hline Cichorium intybus & 3.5 & 32 & $62 *$ & $105^{*}$ \\
\hline Ginkgo biloba & 3.8 & 32 & $64 *$ & $104 *$ \\
\hline Ipomoea batatus & 4.0 & 32 & $68 \%$ & $117 *$ \\
\hline Pinytolacca americana & 4.0 & 32 & $65^{*}$ & $110 *$ \\
\hline Populus tremuloides & 4.8 & 32 & $66 *$ & $109 *$ \\
\hline control & 5.8 & 32 & 83 & 143 \\
\hline
\end{tabular}

(1) for common name see Appendix Table 4.

(2) relative frond area index = final frond area/initial frond area.

(3) all tissues were assayed on 23 inedium.

* Indicates significance at 95\% 1eve1. 


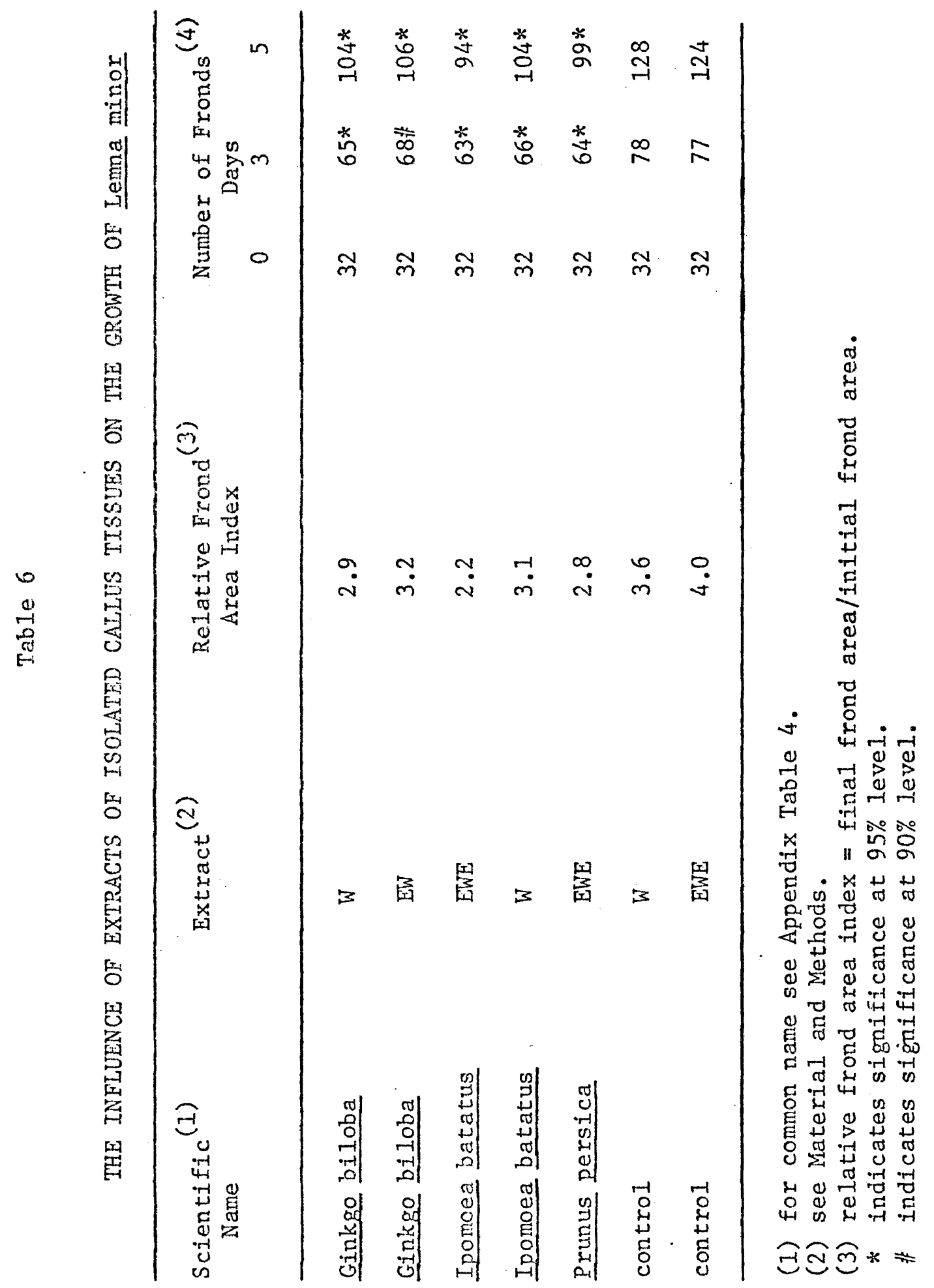




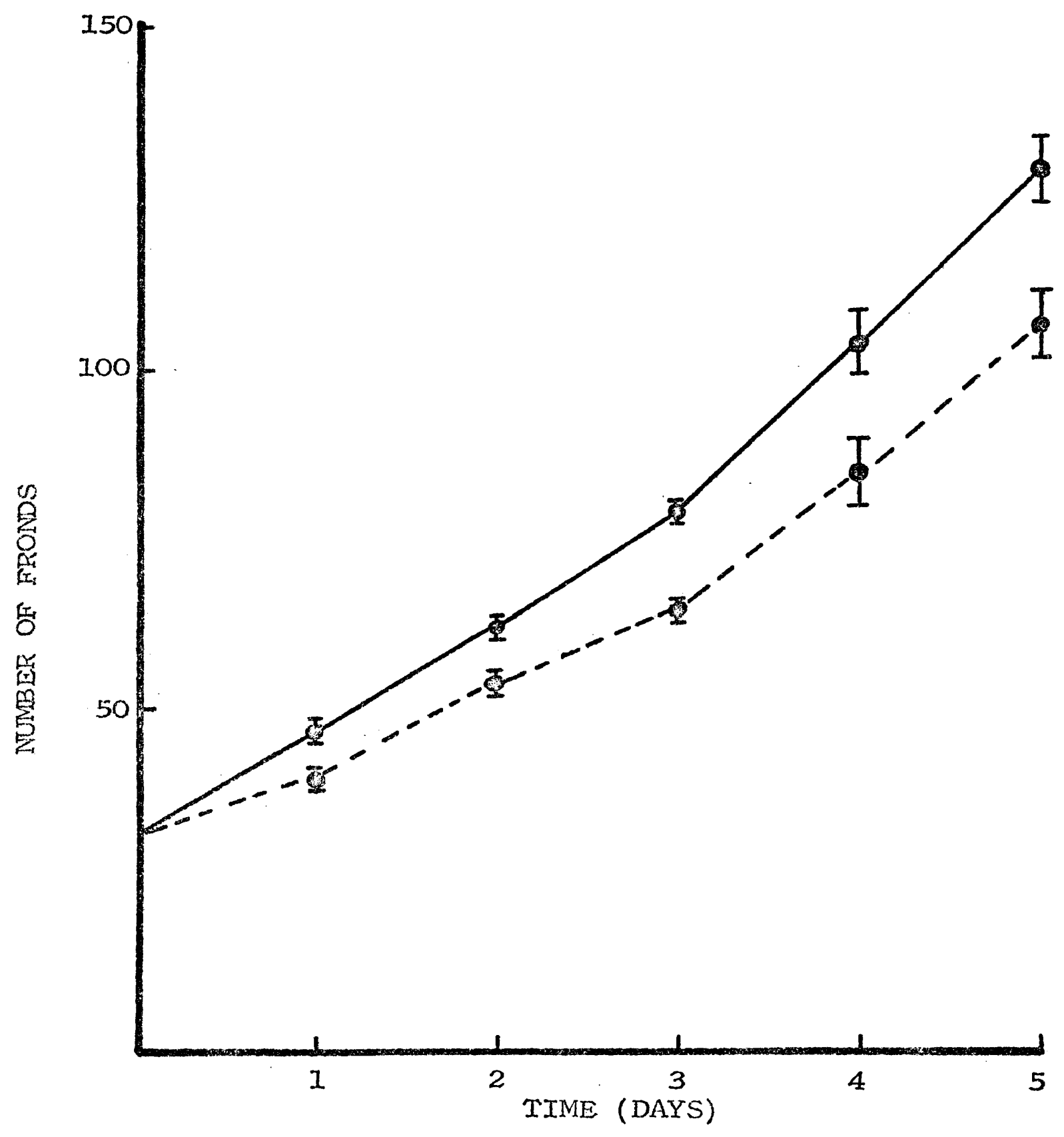

FIGURE 1I. THE GROWTH OF LEMNA IN THE PRESENCE OF WATER EXIRACT OF ISOLATED GINKGO CALLUS TISSUE contro1

ginkgo callus extract $---m-m$

조 - indicates $95 \%$ significant level 
extract had no detectable activity. The inhibition was relatively strong using the $\mathrm{W}$ extract. It can be concluded that the inhibitor of Lemna growth present in the ginkgo callus tissue is water and ethyl ether soluble. Both EWE and $W$ extracts of sweet potato callus tissue demonstrated an inhibition of the growth of Lemna. The inhibitor in EWE extracts was stronger than the material in the $W$ extract. The interaction of these two inhibitors was not studied. An additional. inhibitor of Lemna growth was found in the EWE extract of peach callus tissue (Figure 12). However, an inhibitor was not detected in the secretion of peach callus tissue. The inhibitor present in peach explants was not secreted into the culture medium. Inhibitors of Lemna growth and Chlorel1a were not found in the extracts of pokeberry explants. Growth stimulators were not detected in this experiment. 


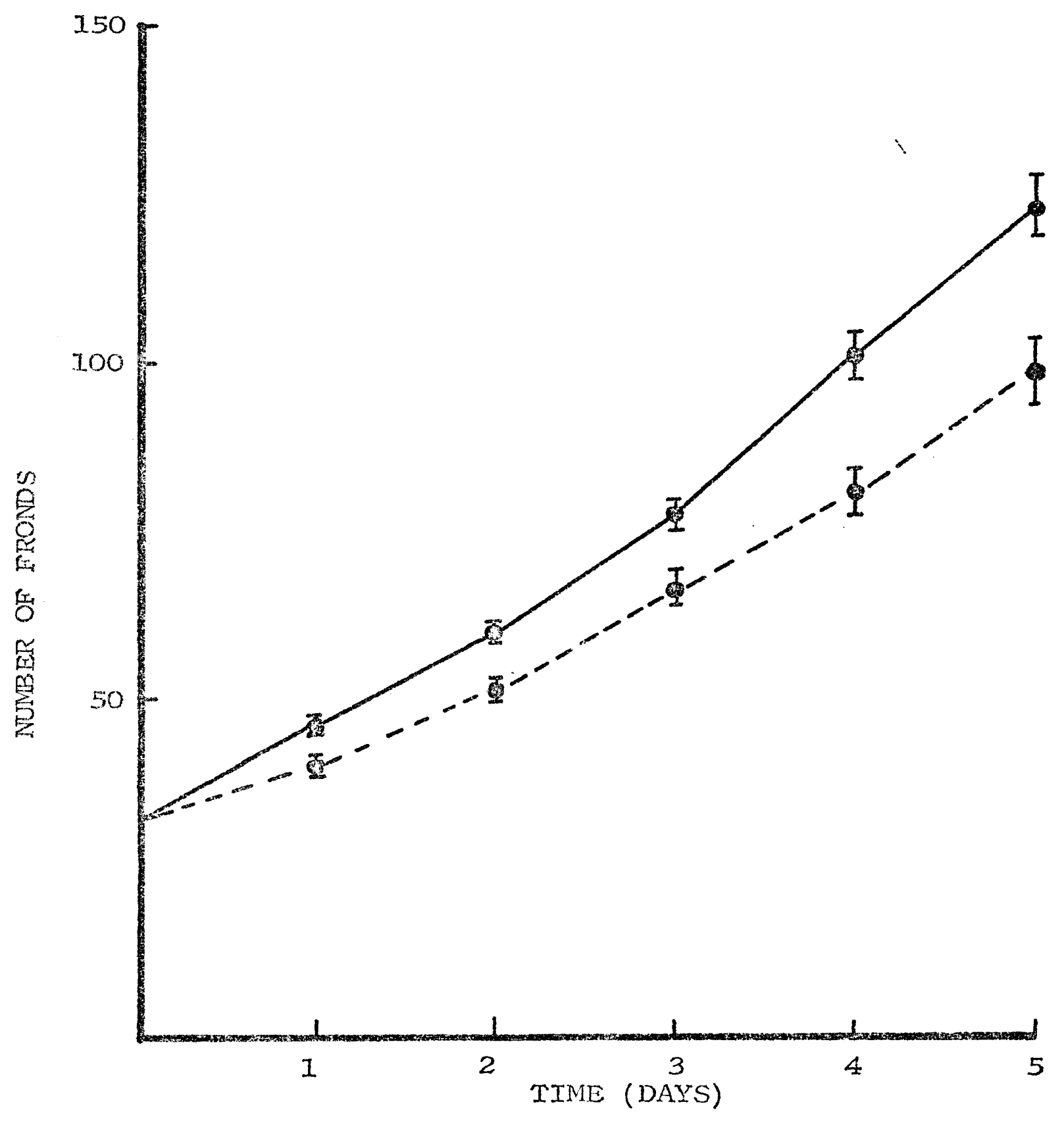

FIGTIRE 12. THE GROWTII OF I.ENINA IN TIIE PRESENCE OF ETHYY ETHER EXTRACT OF ISOLATED PEACH CALIUS TISSUE control

peach callus extract $--m-m-m$

- indicates $95 \%$ significant leve]. 
SUMMARY AND CONCLUSIONS

P1ant naterials were surface sterilized and callus tissues were isolated from a wide variety of plants. The growth of various tissues on different media suggested that callus tissues may require an adaptive growth pexiod. It is suggested that most of the explants have similar nutrient requirements but different callus tissues may require different growth regulators. Isolated callus tissue was obtained from 42. species and used in a number of bioassays to detect growth regulator activity. Forty percent of the callus tissues used in the experiments demonstrated an influence on the growth of assay organisms. Most of the growth influence was inhibitory. Conclusions in this section are based on the results which are summarized in Table 7 .

Antimicrobial activity has been previously reported in the intact: plants of Ginjoro biloba, Prunus persjca, Amelanchier alnifolia, Iromoea purpurea, Juglans nigra, Brassica oleracea var. botrytis, Brassica oleracea var. capitata, Phytolacca americana, Ipomoea batatus, Acex saccharum, Daucus carota, Robinia pseudoacacia, Sambacus canadensis and Solanum tuberosum. Intact Populus tremuloides plants have not been reported to have antimicrobial activity but were found to produce callus with in vitro growth regulatory activity in this study. Antimicrobial activity was also detected in the secretions of Ipomoea batatus, Amelanchier alnjiolia and Phytolacca americana explants. This suggests that callus tissues may produce metabolites which differ from the metabolites in the intact plant.

Secretions of isolated tissues (Populus tremuloides, Amelanchier 


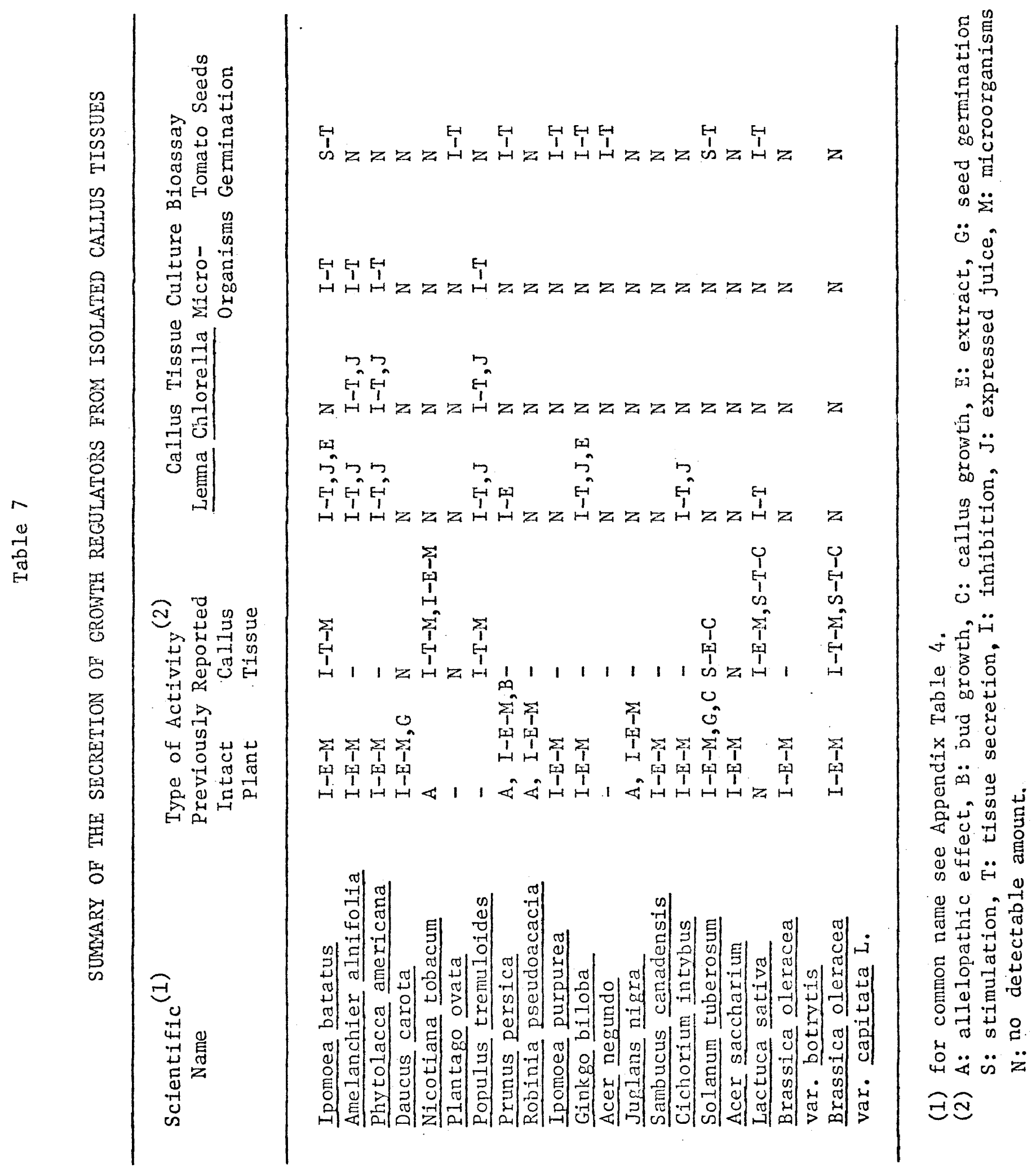


alnifolia, Ipomoea batatus and Phytolacca canadensis) which inhibited the growth of $\underline{B}$. subtilis did not show inhibition using $\underline{\text { E. coli }}$ and S. 1utea. It was suggested that the antibiotic materials have a very narrow spectrum of antimicrobial activity.

Stimulatory influences were found on $1 y$ in the secretion of Ipomoea batatus and Solanum tuberosum explants when the germination of tomato seeds was employed as an assay. Tomato seed germination inhibitors were found in the secretions of Acer negundo, Amelanchier alnifolia, Ipomoea purpurea, Ginkgo biloba, Plantago ovata, Lactuca sativa and prunus persica callus tissues. An influence on the germination of tomato seeds was not detected in the expressed juices of isolated callus tissues which had previously demonstrated regulatory secretions. It is suggested that the growth regulators were inactivated or in very low concentrations in the expressed juice.

An inhibitor of Lemma growth was found in the secretion of Amelanchier aInifolia, Ginkgo biloba, Ipomoea batatus, Cichorum intybus, Phytolacca americana, Populus tremuloides and Lactuca sativa callus tissues. The expressed juice of the above listed explants (except lettuce) also resulted in an jnhibition of Lemna growth. These inhibitors may be secreted into the medium as end products of metabolism or cellular autolysis may release the cell contents, including the inhibitor, into the medium. An inhibitor of the growth of the green alga, Chlore11a sorokiniana, was found in the secretion of Populus tremuloides and Phytolacca americana callus tissues. The expressed juices of these two callus tissues, however, resulted in a slight inhibition of Chlore1la.

An ethyl ether and water soluble inhibitor of Lemna growth was found in Ginkgo biloba explants. The Lema growth inhibitor in Ipomoea 
batatus callus tissue was found to contain a water soluble component and an ethyl ether soluble and water insoluble fraction. An ethyl ether soluble Lemna growth inhibitor was found in the callus tissue of Prunus persica but was not secreted into the culture medium.

In nature plant inhibitors can be produced by the different parts of the plant and may play an important role in plant ecology. The production of natural inhibitors is also subject to seasonal variations. Tissue cultures are grown under a rigidly controlled conditions with minimal physical, chemical or environmental fluctuations. The results from this study indicate that tissue culture represents an important method useful in the detection of new materials which may not be detected or produced in nature. This in vitro system also provides a method for obtaining information concerning the influence of different chemical and physical factors on the secretion of regulatory materials. In this study two plants that had not been reported to have stimulatory influences were found to stimulate tomato seed germination. Intact plants of Plantago ovata, Populus tremuloides, Acer negundo and Lactuca sativa have not been reported to have growth regulatory activity in nature. Callus tissues from these plants were, however, found to secrete inhibitors into the culture media. Fifty percent of the plants which produce growth regulatory materials in nature also produced callus tissue which was capable of regulating growth of assay organisms. It is concluded that tissue grown in vitro may produce the same or different growth regulators as the intact plants. 


\section{APPENDIX}

TABLE I

THE COMPOSITION OF THE STANDARD MEDIUM (NUMBER 23)

Chemical

Concentration--mg/1iter

$\mathrm{CaNO}_{3} \cdot 4 \mathrm{H}_{2} \mathrm{O}$

200

$\mathrm{MgSO}_{4} \cdot 7 \mathrm{H}_{2} \mathrm{O}$

360

$\mathrm{Na}_{2} \mathrm{SO}_{4}$

200

$\mathrm{KNO}_{3}$

80

$\mathrm{KC1}$

66

$\mathrm{NaH}_{2} \mathrm{HO}_{4} \cdot \mathrm{H}_{2} \mathrm{O}$

16

Ferric citrate

10

$\mathrm{MnSO}_{4}$

3

$\mathrm{CuSO}_{4} \cdot 5 \mathrm{H}_{2} \mathrm{O}$

0.025

$\mathrm{Na}_{2} \mathrm{MO}_{4} \cdot 2 \mathrm{H}_{2} \mathrm{O}$

0.025

$\mathrm{H}_{2} \mathrm{SO}_{4}$ (sp. gr. 1.84 )

$0.0005 \mathrm{ml} / 1$ iter

$\mathrm{H}_{3} \mathrm{BO}_{3}$

0.05

$\mathrm{ZnSO}_{4} \cdot 7 \mathrm{H}_{2} \mathrm{O}$

0.05

Agar (1)

8000

Sucrose

20000

Naphthalene Acetic Acid

0.50

Coconut milk (2)

$100 \mathrm{~m} 1$

(1) omitted from 1iquid medium.

(2) heated to $60^{\circ} \mathrm{C}$, cooled and filtrated before incorporation into the medium. 
TABLE 2

THE COMPOSITION OF LINSMAIER AND SKOOG'S DEFINED MEDIUM

Chemical

Concentration--ng/1iter

$\mathrm{NH}_{4} \mathrm{NO}_{3}$

1650

$\mathrm{CaCl}_{2} \cdot 2 \mathrm{H}_{2} \mathrm{O}$

440

$\mathrm{KH}_{2} \mathrm{PO}_{4}$

170

$\mathrm{Na}_{2}$ EDTA

37.3

$\mathrm{FeSO}_{4} \cdot 7 \mathrm{H}_{2} \mathrm{O}$

27.8

$\mathrm{MgSO}_{4} \cdot 7 \mathrm{H}_{2} \mathrm{O}$

370

$\mathrm{KNO}_{3}$

1900

$\mathrm{H}_{3} \mathrm{BO}_{3}$

6.2

$\mathrm{MnSO}_{4} \cdot \mathrm{H}_{2} \mathrm{O}$

17.1

$\mathrm{ZnSO}_{4} \cdot 7 \mathrm{H}_{2} \mathrm{O}$

10.7

$\mathrm{KI}$

0.83

$\mathrm{Na}_{2} \mathrm{MoO}_{4} \cdot 2 \mathrm{H}_{2} \mathrm{O}$

0.25

$\mathrm{CuSO}_{4} \cdot 5 \mathrm{H}_{2} \mathrm{O}$

0.025

$\mathrm{CoCl}_{2} \cdot 6 \mathrm{H}_{2} \mathrm{O}$

0.025

Kinetin (1)

0.2

Indoleacetic Acid (1)

2.0

Agar

8000

Sucrose

30000

Thiamine $\mathrm{HCl}$

0.40

Inositol

100

$\mathrm{pH}$ adjusted to 5.6 with $1 \mathrm{~N} \mathrm{NaOH}$

(1) omitted in the $1.0 \mathrm{ppm} 2.4-\mathrm{D}$ medium. 
TABLE 3

THE COMPOSITION OF THE HYDROPONIC SOLUTION

Chemical

$\mathrm{MgSO}_{4} \cdot 7 \mathrm{H}_{2} \mathrm{O}$

$\mathrm{Ca}\left(\mathrm{NO}_{3}\right)_{2} \cdot 4 \mathrm{H}_{2} \mathrm{O}$

$\mathrm{KH}_{2} \mathrm{PO}_{4}$

$\mathrm{FeSO}_{4} \cdot 7 \mathrm{H}_{2} \mathrm{O}$

Na EDTA

$\mathrm{H}_{3} \mathrm{BO}_{3}$

$\mathrm{MCl} I_{2} \cdot \mathrm{H}_{2} \mathrm{O}$

$\mathrm{ZnSO}_{4} \cdot 7 \mathrm{H}_{2} \mathrm{O}$

$\mathrm{CuCl}_{2} \cdot 2 \mathrm{H}_{2} \mathrm{O}$

Adjust: $\mathrm{pH}$ to 5.6
Concentration--ing/1iter

4920

9400

2720

$7.5^{(1)}$

5.6

$3.0^{(2)}$

7.2

0.84

0.16

(1) Fe concentration was 1 ppm.

(2) B concentration was $0.5 \mathrm{ppm}$. 
TABLE 4

LISTING OF PLANTS USED AS A SOURCE OF CALLUS TISSUE

\begin{tabular}{|c|c|c|c|c|}
\hline $\begin{array}{l}\text { Common Name } \\
\text { (Scientific Name) }\end{array}$ & $\begin{array}{l}\text { Source of } \\
\text { Tissue }\end{array}$ & $\begin{array}{l}\text { Tissue } \\
\text { Sterility }\end{array}$ & $\begin{array}{l}\text { Callus } \\
\text { Growth }\end{array}$ & Assay \\
\hline $\begin{array}{l}\text { peach } \\
\text { (Prunus persica) }\end{array}$ & stem $^{(1)}$ & + & + & + \\
\hline $\begin{array}{l}\text { honeysuckle } \\
\text { (Lonicera japonica) }\end{array}$ & stem & + & + & - \\
\hline $\begin{array}{l}\text { goldenrod } \\
\text { (Solidago canadensis) }\end{array}$ & stem & + & + & - \\
\hline $\begin{array}{l}\text { serviceberry } \\
\text { (Anelanchier alnifolia) }\end{array}$ & stem & + & + & + \\
\hline $\begin{array}{l}\text { willow } \\
\text { (Salix alba) }\end{array}$ & stem & + & + & - \\
\hline $\begin{array}{l}\text { red mulberry } \\
\text { (Morus rubra) }\end{array}$ & stem & + & + & - \\
\hline $\begin{array}{l}\text { buckthorn } \\
\text { (Rhamnus cathartica) }\end{array}$ & stem & + & + & - \\
\hline $\begin{array}{l}\text { Iilac } \\
\text { (Syringa vulgaris) }\end{array}$ & stem & + & + & - \\
\hline $\begin{array}{l}\text { black locust } \\
\text { (Robinia pseudoacacia) }\end{array}$ & stem & + & + & + \\
\hline $\begin{array}{l}\text { morning glory } \\
\text { (Ipomoea purpurea) }\end{array}$ & stem & + & + & + \\
\hline $\begin{array}{l}\text { wild rose } \\
\text { (Rosa virginiana) }\end{array}$ & stem & + & + & - \\
\hline $\begin{array}{l}\text { beech } \\
\text { (Fagus grandifolia) }\end{array}$ & stem & + & - & - \\
\hline $\begin{array}{l}\text { pokeberry } \\
\text { (Phytolacca americana) }\end{array}$ & stem & + & + & + \\
\hline $\begin{array}{l}\text { ginkgo } \\
\text { (Ginkgo biloba) }\end{array}$ & stem & + & + & + \\
\hline
\end{tabular}


TABLE 4 (continued)

LISTING OF PLANTS USED AS A SOURCE OF CALLUS TISSUE

\begin{tabular}{|c|c|c|c|c|}
\hline $\begin{array}{l}\text { Common Name } \\
\text { (Scientific Name) }\end{array}$ & $\begin{array}{l}\text { Source of } \\
\text { Tissue }\end{array}$ & $\begin{array}{l}\text { Tissue } \\
\text { Sterility }\end{array}$ & $\begin{array}{l}\text { Ca11us } \\
\text { Growth }\end{array}$ & Assay \\
\hline $\begin{array}{l}\text { dog fennel } \\
\text { (Anthemis cotula) }\end{array}$ & stem & + & - & - \\
\hline $\begin{array}{l}\text { sweet gum } \\
\text { (Liguidambar styraciflua L.) }\end{array}$ & stem & + & + & - \\
\hline $\begin{array}{l}\text { white poplar } \\
\text { (Populus alba L.) }\end{array}$ & stem & + & + & - \\
\hline $\begin{array}{l}\text { black gum } \\
\text { (Nyssa sylvatica) }\end{array}$ & stem & - & - & - \\
\hline $\begin{array}{l}\text { Virginia creeper } \\
\text { (Parthenocissus quinquefolia) }\end{array}$ & stem & - & - & - \\
\hline $\begin{array}{l}\text { patridgeberry } \\
\text { (Mi.tche11a repens L.) }\end{array}$ & stem & + & - & - \\
\hline $\begin{array}{l}\text { patridgeberry } \\
\text { (Mitche1la repens L.) }\end{array}$ & fruit & + & - & - \\
\hline $\begin{array}{l}\text { holly } \\
\text { (Ilex opaca) }\end{array}$ & stem & + & + & - \\
\hline $\begin{array}{l}\text { box elder } \\
\text { (Acer negundo) }\end{array}$ & stem & + & + & + \\
\hline $\begin{array}{l}\text { tree of heaven } \\
\text { (Alianthus altissima) }\end{array}$ & stem & - & - & - \\
\hline $\begin{array}{l}\text { black walnut } \\
\text { (Juglans nigra) }\end{array}$ & stem & + & - & - \\
\hline $\begin{array}{l}\text { black walnut } \\
\text { (Juglans nigra) }\end{array}$ & fruit & + & + & + \\
\hline $\begin{array}{l}\text { cotton } \\
\text { (Gossypium herbaceum) }\end{array}$ & petiole & + & + & - \\
\hline $\begin{array}{l}\text { cotton } \\
\text { (Gossypium herbaceum) }\end{array}$ & stem & - & - & - \\
\hline
\end{tabular}


TABLE 4 (continued)

LISTING OF PLANTS USED AS A SOURCE OF CALLUS TISSUE

\begin{tabular}{|c|c|c|c|c|}
\hline $\begin{array}{l}\text { Common Name } \\
\text { (Scientific Name) }\end{array}$ & $\begin{array}{l}\text { Source of } \\
\text { Tissue }\end{array}$ & $\begin{array}{l}\text { Tissue } \\
\text { Sterility }\end{array}$ & $\begin{array}{l}\text { Callus } \\
\text { Growth }\end{array}$ & Assay \\
\hline $\begin{array}{l}\text { elderberry } \\
\text { (Sambucus canadensis) }\end{array}$ & stem & + & + & + \\
\hline $\begin{array}{l}\text { white birch } \\
\text { (Betula alba) }\end{array}$ & stem & + & + & - \\
\hline $\begin{array}{l}\text { nightshade } \\
\text { (Solanum americanum) }\end{array}$ & fruit & + & + & - \\
\hline $\begin{array}{l}\text { apple } \\
\text { (pyrus malus) }\end{array}$ & stem & + & + & - \\
\hline $\begin{array}{l}\text { blue flower chicory } \\
\text { (Cichorium intybus) }\end{array}$ & stem & + & + & + \\
\hline $\begin{array}{l}\text { wormwood } \\
\text { (Artemisia absinthium) }\end{array}$ & stem & - & - & - \\
\hline $\begin{array}{l}\text { ragweed } \\
\text { (Ambrosia artemisifolia) }\end{array}$ & stem & - & - & - \\
\hline $\begin{array}{l}\text { horseweed } \\
\text { (Erigeron canadensis) }\end{array}$ & stem & - & - & - \\
\hline $\begin{array}{l}\text { pigweed } \\
\text { (Chenopodium alba) }\end{array}$ & stem & - & - & - \\
\hline $\begin{array}{l}\text { periwinkle } \\
\text { (Vinca major) }\end{array}$ & stem & - & - & - \\
\hline $\begin{array}{l}\text { balsam } \\
\text { (Impatiens pallida) }\end{array}$ & stem & - & - & - \\
\hline $\begin{array}{l}\text { dogwood } \\
\text { (Cornus canadensis) }\end{array}$ & stem & - & - & - \\
\hline $\begin{array}{l}\text { turlip poplar } \\
\text { (Liriodendron tulipifera) }\end{array}$ & stem & - & - & - \\
\hline $\begin{array}{l}\text { strawberry-bush } \\
\text { (Euonymus americanus) }\end{array}$ & stem & - & - & - \\
\hline
\end{tabular}


TABLE 4 (continued)

LISTING OF PLANTS USED AS A SOURCE OF CALLUS TISSUE

\begin{tabular}{|c|c|c|c|c|}
\hline $\begin{array}{l}\text { Common Name } \\
\text { (Scientific Name) }\end{array}$ & $\begin{array}{l}\text { Source of } \\
\text { Tissue }\end{array}$ & $\begin{array}{l}\text { Tissue } \\
\text { Sterility }\end{array}$ & $\begin{array}{l}\text { Callus } \\
\text { Growth }\end{array}$ & Assay \\
\hline $\begin{array}{l}\text { strawberry-bush } \\
\text { (Euonymus americanus) }\end{array}$ & fruit & + & - & - \\
\hline $\begin{array}{l}\text { white potato }(2) \\
\text { (Solanum tuberosum) }\end{array}$ & tuber & + & + & + \\
\hline $\begin{array}{l}\text { cauliflower } \\
\text { (Brassica oleracea } \\
\text { var. capitata } L_{.} \text {) }\end{array}$ & $\begin{array}{l}\text { stem } \\
\text { pith }\end{array}$ & + & + & + \\
\hline $\begin{array}{l}\text { cabbage } \\
\text { (Brassica oleracea } \\
\text { var. botrytis) }\end{array}$ & $\begin{array}{l}\text { stem } \\
\text { pith }\end{array}$ & + & + & + \\
\hline $\begin{array}{l}\text { lettuce } \\
\text { (Lactuca sativa) }\end{array}$ & $\begin{array}{l}\text { stem } \\
\text { pith }\end{array}$ & + & + & + \\
\hline $\begin{array}{l}\text { sugar maple } \\
\text { (Acer saccherum) }\end{array}$ & root & + & + & + \\
\hline $\begin{array}{l}\text { Sweet potato }(2) \\
\text { (Ipomoea batatus) }\end{array}$ & stem & + & + & + \\
\hline $\begin{array}{l}\text { carrot }(2) \\
\text { (Dacus carota) }\end{array}$ & stem & + & + & + \\
\hline $\begin{array}{l}\text { plantain }(2) \\
\text { (Plantago ovata) }\end{array}$ & stem & + & + & + \\
\hline $\begin{array}{l}\text { tobacco }(2) \\
\text { (Nicotiana tobacum) }\end{array}$ & stem & + & + & + \\
\hline $\begin{array}{l}\text { aspen-triploid }(2) \\
\text { (Populus tremuloides) }\end{array}$ & stem & + & + & + \\
\hline
\end{tabular}

(1.) stem-indicates tissue derived from cambial area.

(2) isolated callus tissue obtained from Dr. Mathes, Dept. of Biology, College of William \& Mary. 
TABLE 5

THE HYDROGEN ION CONCENTRATION OF TISSUE CULTURE MEDIUM

AFTER SUPPORTING THE GROWTH OF ISOLATED CALLUS TISSUES

\begin{tabular}{llll}
\hline Scientific Name (I) & Medium & $\begin{array}{c}\mathrm{pH} \text { of } \\
\text { Medium }\end{array}$ & $\begin{array}{c}\text { pH of Area Where } \\
\text { Tissue Had Grown }\end{array}$ \\
\hline PIantago ovata & 23 & 6,0 & 5.8 \\
\hline Acer saccharum & IK & 5.4 & 5.1 \\
Ipomoea batatus & IK & 5.4 & 5.2 \\
Daucus carota & IK & 5.4 & 5.2 \\
Nicotiana tabacum & 23 & 5.3 & 5.2 \\
Populus tremuloides & 23 & 5.6 & 5.2 \\
Prunus persica & $2,4-\mathrm{D}$ & 5.0 & 5.0 \\
Amelanchier alnifolia & $2,4-\mathrm{D}$ & 5.0 & 4.9 \\
Robinia pseudoacacia & $2,4-\mathrm{D}$ & 5.4 & 5.4 \\
Ipomoea purpurea & $2,4-\mathrm{D}$ & 5.5 & 5.3 \\
Phytolacca americana & $2,4-\mathrm{D}$ & 5.2 & 5.0 \\
Ginkgo biloba & $2,4-\mathrm{D}$ & 5.3 & 5.3 \\
Acer negundo & $2,4-\mathrm{D}$ & 5.1 & 4.9 \\
Sambucus canadensis & $2,4-\mathrm{D}$ & 4.9 & 4.9 \\
Cichorium intybus & $2,4-\mathrm{D}$ & 5.0 & 4.9 \\
Solanum tuberosum & 23 & 5.0 & 4.9 \\
- & & & \\
\hline
\end{tabular}

(1) for common name see Appendix Table 4.

(2) the $\mathrm{pH}$ of control media was 5.8 (23), 5.5 (IK) and $5.6(2,4-\mathrm{D})$ in the absence of tissue growth.

(3) the growth period was approximately 4 weeks. 


\section{BIBLIOGRAPHY}

Al-Naib, F. A., and Rice, E. L. 1971. Allelopathic effects of platanus occidentalis. Bull. Torrey Bot. Club 98: 75-82.

Ballantyne, D. J. 1962. A growth inhibitor from the roots of Chrysanthemum morifolium Ramat. and its influence upon the gibberellic acid response. Can. J. Bot. 40: 1229-1235.

Barker, W. G. 1970. Influence of metabolites produced by explants of carrot, potato, lettuce, and cauliflower on the growth of other explants. Can. J. Bot. 48: 887-890.

Baskin, J. M., Ludlow, C. J., Harris, T. M. and Wolf, F. T. 1967. Psoralea subacaulis (Leguminosae). Phytochem. 6: 1209-1213.

Benedict, H. M. 1941. The inhibitory effect of dead roots on the growth of brome grass. J. Am. Soc. Agron. 33: 1108-1109.

Bode, N. R. 1939. Ueber die blattausscheidung des wermuts und ihre wirkung auf andere pflanzen. Planta 30: 566.

Bonner, H. 1959. The apple replant problem. I. The excretion of phlorizin from apple residues. Contr. Boyce Thompson Inst. 20: 39-56.

Bonner, J. 1950. The role of toxic substances in the interactions of higher plants. Bot. Rev. 16: 51-65.

Campbe11, G., Chan, E. C. S., and Barker, W. G. 1965. Growth of lettuce and cauliflower tissue in vitro and their production of antimicrobial. metabolites. Can. J. Microbio1. 11: 785-788.

Carley, H. E., and Watson, R. D. Effect of various aqueous plant extracts upon seed germination. Bot. Gaz. 129: 57-62.

Cook, M. T. 1921. Wilting cause by walnut tree. Phytopath. 11: 346.

Corgan, J. N. 1965. Seasonal change in naringenin concentration in peach flower buds. Proc. Am. Soc. Hort. Sci. 86: 129-132.

Corman, I. 1946. Alteration of mitosis by coumarin and parasobic acid. Am. J. Bot. 33: 217.

Culter, H. G. 1970. A growth inhibitor from young expanding tobacco leaves. Science 170: 856-857.

Davis, R. F. 1928. The toxic principle of Juglans nigra as identifjed with synthetic juglone and its toxic effects on tomato and alfalfa plants. Ani. J. Bot. 15: 620 . 
Davison, R. M. 1965. Some properties of a plant growth inhibitor present in xylem sap of woody species. Aust. J. Biol. 18: 475-486.

Decandolle, A. 1832. Physiologie vegetal.

Dennis, F. G. Jr., and Edgerton, L. J. 1967. The relationship between an inhibitor and rest in peach flower buds. Proc. Am. Soc. Hort. Sci. 77: $107-116$.

Erez, A., and Lavee, S. 1969. Prunin identification, biological activity and quantitative change in comparison to naringenin in dormant peach buds. Plant Physiol. 44: 342-346.

Funke, G. 1943. The influence of Artemisia absinthium on neighboring plants. Blumea 5: 281-293.

Gorham, P. R. 1941. Measurement of the response of Lemna to growth promoting substances. Am. J. Bot. 28: 98-101.

Gray, R., and Bonner, J. 1948. An inhibitor of plant growth from the leaves of Encelia farinosa. Am. J. Bot. 35: 52-57.

and J. 1948. Structure determination and synthesis of a plant growth inhibitor 3-acety1-6-methoxy-benzaldehyde, found in the leaves of Encelia farinosa. J. Am. Chem. Soc. 70: 1249-1253.

Girouard, R. M., and Hess, C. E. 1964. The diffusion of root promoting stibstances from stems of Hedera helix. Comb. Proc. Int. P1. Prop. Soc. 14: $162-166$.

Hamilton, K. C., and Buchholtz, K. P. 1.955. Effect of rhizomes of quackgrass species. Ecology 36: 304-308.

Hendershott, C. H., and Walker, D. R. 1959. Identification of a growth inhibjtor from extracts of dormant peach flower buds. Science 130: 2278 .

and - 1959. Seasonal fluctuations in quantity of growth substances in resting peach flower buds. Proc. Am. Soc. Hort. Sci. 74: $121-129$.

Hicks, L. E. 1937. The Lemnaceae of Indiana. Am. Mid. Nat. 18: 774-789.

Kawase, M. 1970. Root-promoting substances in Salix alba. Physiol. Plant. 23: $159-170$.

Khanna, P., and Stabe, E. J. 1968. Antimicrobials from plant tissue cultures. Lloydia 31: 180-189.

Klein, R. M. 1960. Plant tissue cultures, a possible source of plant constituents. Econ. Bot. 14: 286-289.

Kommedah1, T., Kotheimer, J. B., and Bernardini, J. V. 1959. The effects of quackgrass on germination and seedling development of certain crop plants. Weeds 7: 1-12. 
Linsmaier, E. M., and Skoog, F. 1965. Organic growth requirements of tobacco tissue cultures. Physiol. Plant. 18: 100-127.

Lodhi, M. A. K., and Rice, E. L. 1971. Allelopathic effects of Celtis laevigata. Bul1. Torrey Bot. Club 98: 83-89.

Maheshwari, R., Hildebrandt, A. C., and Allen, P. J. 1967. Factors affecting the growth of rust fungi on host tissue cultures. Bot. Gaz. 128: 153-159.

Major, R. T. 1967. The ginkgo, the most ancient living tree. Science 157: $1270-1273$.

Massey, A. B. 1925. Antagonism of the walnuts (Juglans nigra L. and Juglans cinerea $\left.L_{0}\right)$ in certain plant associations. Phytopath. 15: $773 \cdots 784$.

Mathes, M. C. 1964. Antimicrobial substances from aspen tissue grown in vitto. Science 140: 1101-1102.

- 1967. The secretion of antimicrobial materials by various isolated plant tissues. Lloydia 30: 177-181.

- 1967. The in vitro growth of Acer saccharum and Acer pennsylvanicum callus tissue. Can. J. Bot. 45: 2195-2200.

, Morese11i, M., and Marvin, J. W. 1971. The in vitro growth and metabolism of Acer saccharum tissue. Can. J. Bot. 49: 495-500.

Muller, W. H. 1965. Volatile materials produced by Salvia Ieucophy11a: . effects; on seedling growth and soil bacteria. Bot. Gaz. 126: 195-200. and Muller, C. H. 1964. Volatile growth inhibitors produced by Salvia species. Bu11. Torrey Bot. Club 91: 327-330.

Murashige, T., and Skoog, F. 1962. A revised medium for rapid growth and bioassays with tobacco tissue cultures. Physiol. Plant. 15: 473-497.

Nicke11, L. G. 1960. Antimicrobial activity of vascular plants. Econ. Bot. 13: $281-318$.

Nitsch, J. P. 1951. Growth and development in vitro of excised ovaries. Anu. J. Bot. 38: 566-576.

Ohman, J. H., and KommedahI, T. 1960. Relative toxicity of extracts from vegetative organs of quackgrass to alfalfa. Weeds 8: 666-670.

Osborn, E. M. 1943. On the occurrence of antimicrobial substances in green plants. Brit. J. Exp. Path. 24: 227-231.

Osvald, H. 1948. Toxic exudates from the roots of Agropyron repens. J. Ecol. 36: 192-193.

Patrick, Z. A. 1955. The peach replant problem in Ontario. II. Toxic substances from microbiological decomposition products of peach root residues. Can. J. Bot. 33: $461-486$. 
Patrick, Z. A., Toussoun, T. A., and Koch, L. W. 1964. Effect of crop residue decomposition on plant roots. Ann. Rev. Phytopatho1. 2: 267-292.

Perry, G. S. 1932. Some tree antagonisms. Proc. Pa. Acad. Sci. 6: 136-141.

Proebsting, E. L., and Gilmore, A. E. 1940. The relation of peach root toxicity to the re-establishing of peach orchards. Proc. Am. Soc. Hort. Sci. 38: 21-26.

Rajasekhar, E. W., Edwards, M., Wilson, S. B., and Street, H. E. 1971. Studies on the growth in culture of plant cells. XI. The influence of shaking rate on the growth of suspension cultures. J. Exp. Bot. 22 : $107-117$.

Robinson, P. M., and Wareing, P. F. 1964. Chemical nature and biological properties of the inhibitor varying with photoperiod in sycamore (Acer pseudoplatanus). Physio1. Plant. 17: 31.4-323.

Rovira, A. D. 1969. Plant root exudates. Bot. Rev. 35: 35-57.

Schneiderhan, F. J. 1927. The black walnut (Juglans nigra L.) as a caise of the death of apple trees. Phytopath. 17: 529-540.

Steward, F. C., and Caplin, S. M. 1952. Investigations on growth and metabolism of plant cells. III. Evidence for growth inhibitors in certain mature tissues. Ann. Bot., N. S. XVI: 477-489.

Tukey, H. B. Ir. 1969. Implications of allelopathy in agricultural plant science. Bot. Rev. 35: 1-16.

Tulecke, W., and Nicke1I, L. G. 1959. Production of large amounts of plant tissue by submerged culture. Science 130: 863-864.

Voigt, G. K., and Mergen, F. 1962. Seasonal variation in toxicity of Ailanthus leaves to pine seedlings. Bot. Gaz. 123: 262-265.

Waks, C. 1936. The influence of extracts of Robinia pseudoacacia on the growth of barley. Pub. Fac. Sci. Univ. Charles, [Praha]. 150: 84-85.

Weinstein, L. H., Nicke11, L. G., and Laurencot, H. J. Jr. 1962. Biochemical and physiological studies of tissue cultures and the parts from which they are derived. III. Paul's scarlet rose. Contrib. Boyce Thompson Inst. 21: 371-386.

Welbank, P. J. 1963. Toxin production during decay of Agropyron repens (couch grass) and other species. Weed Res. 3: 205-214.

White, P. R. 1942. Plant tissue cultures. Ann. Rev. Biochem. 2: 615-628.

Woods, F. W. 1960. Biological antagonisms due to phytotoxic root exudates. Bot. Rev. 26: 546-569.

Yeoman, M. M., Naik, G. G., and Robertson, A. I. 1968. Growth and differentiation of plant tissue cultures. MTI. The initiation and pattern of cell division in developing callus cultures. Ann. Bot. 32: 301-313. 
VITA

\section{Alan Lung-Ming Lin}

Bom in Szuchuan, China, July 18, 1945. Graduated from Middle School of National Taiwan Norrial University in Taiwan, China, June 1964. Graduated from Fu-Jen Catholic University, B. S., 1968. Served in China Arny as an Rolc officer fron July, 1968 to July, 1969 in Taiwan, China. Initiated greduate work in September, 1969, at the College of William and Mary in the Department of Diolvgy. 